\title{
HIV-1 Antiretroviral Drug Therapy
}

\author{
Eric J. Arts ${ }^{1}$ and Daria J. Hazuda ${ }^{2}$ \\ ${ }^{1}$ Ugandan CFAR Laboratories, Division of Infectious Diseases, Department of Medicine, Case Western \\ Reserve University, Cleveland, Ohio 44106 \\ ${ }^{2}$ Merck Research Laboratories, West Point, Pennsylvania 19486 \\ Correspondence: eja3@case.edu; daria_hazuda@merck.com
}

\begin{abstract}
The most significant advance in the medical management of HIV-1 infection has been the treatment of patients with antiviral drugs, which can suppress HIV-1 replication to undetectable levels. The discovery of HIV-1 as the causative agent of AIDS together with an everincreasing understanding of the virus replication cycle have been instrumental in this effort by providing researchers with the knowledge and tools required to prosecute drug discovery efforts focused on targeted inhibition with specific pharmacological agents. To date, an arsenal of 24 Food and Drug Administration (FDA)-approved drugs are available for treatment of HIV-1 infections. These drugs are distributed into six distinct classes based on their molecular mechanism and resistance profiles: (1) nucleoside-analog reverse transcriptase inhibitors (NNRTIs), (2) non-nucleoside reverse transcriptase inhibitors (NNRTIs), (3) integrase inhibitors, (4) protease inhibitors (PIs), (5) fusion inhibitors, and (6) coreceptor antagonists. In this article, we will review the basic principles of antiretroviral drug therapy, the mode of drug action, and the factors leading to treatment failure (i.e., drug resistance).
\end{abstract}

\section{BASIC PRINCIPLES OF ANTIRETROVIRAL THERAPY}

Refore 1996, few antiretroviral treatment Boptions for HIV-1 infection existed. The clinical management of HIV-1 largely consisted of prophylaxis against common opportunistic pathogens and managing AIDS-related illnesses. The treatment of HIV-1 infection was revolutionized in the mid-1990s by the development of inhibitors of the reverse transcriptase and protease, two of three essential enzymes of HIV-1, and the introduction of drug regimens that combined these agents to enhance the overall efficacy and durability of therapy. A timeline of antiretroviral drug development and approval for human use is described in Figure 1.

Since the first HIV-1 specific antiviral drugs were given as monotherapy in the early 1990s, the standard of HIV-1 care evolved to include the administration of a cocktail or combination of antiretroviral agents (ARVs). The advent of combination therapy, also known as HAART, for the treatment of HIV-1 infection was seminal in reducing the morbidity and mortality associated with HIV-1 infection and AIDS (Collier et al. 1996; D’Aquila et al. 1996; Staszewski et al. 1996). Combination antiretroviral therapy dramatically suppresses viral replication and reduces the plasma HIV-1 viral load (vLoad) to below the limits of detection of the

Editors: Frederic D. Bushman, Gary J. Nabel, and Ronald Swanstrom

Additional Perspectives on HIV available at www.perspectivesinmedicine.org

Copyright (C) 2012 Cold Spring Harbor Laboratory Press; all rights reserved; doi: 10.1101/cshperspect.a007161

Cite this article as Cold Spring Harb Perspect Med 2012;2:a007161 
$8_{\mathrm{CSH}}^{\infty} \&$ Cold Spring Harbor Perspectives in Medicine

PERSPECTNES

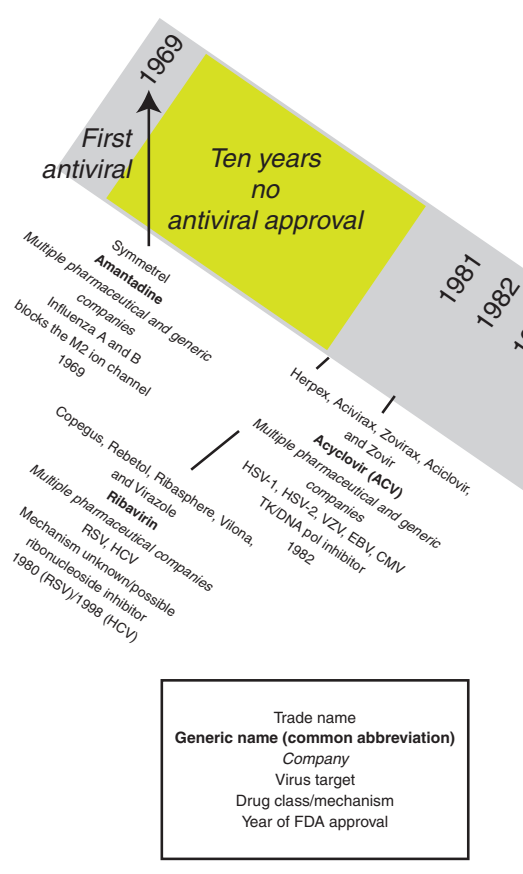

ANTIVIRALS

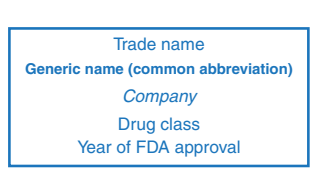

ANTIRETROVIRALS

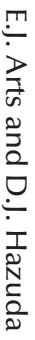

Figure 1. Timeline for FDA approval for current antiviral and antiretroviral drugs. 
most sensitive clinical assays ( $<50$ RNA copies / $\mathrm{mL}$ ) resulting in a significant reconstitution of the immune system (Autran et al. 1997; Komanduri et al. 1998; Lederman et al. 1998;) as measured by an increase in circulating $\mathrm{CD}^{+}{ }^{+}$T-lymphocytes. Importantly, combination therapy using three antiretroviral agents directed against at least two distinct molecular targets is the underlying basis for forestalling the evolution drug resistance.

In an untreated individual, on average there are $10^{4}-10^{5}$ or more HIV-1 particles per $\mathrm{mL}$ of plasma, which turn over at a rate of $\sim 10^{10} / \mathrm{d}$ (Ho et al. 1995; Wei et al. 1995; Perelson et al. 1996). Owing to the error-prone reverse transcription process, it is estimated that one mutation is introduced for every 1000-10,000 nucleotides synthesized (Mansky and Temin 1995; O’Neil et al. 2002; Abram et al. 2010). As the HIV-1 genome is $\sim 10,000$ nucleotides in length, one to 10 mutations may be generated in each viral genome with every replication cycle. With this enormous potential for generating genetic diversity, HIV-1 variants with reduced susceptibility to any one or two drugs will often preexist in the viral quasispecies before initiating therapy (Coffin 1995). The success of HAART results in part from using drug combinations that decrease the probability of selecting virus clones (from an intrapatient HIV-1 population) bearing multiple mutations and conferring resistance to a three-antiretroviral-drug regimen.

Given the rate of HIV-1 turnover and the size of the virus population, mathematical modeling studies have suggested that any combinations in which at least three mutations are required should provide durable inhibition (Frost and McLean 1994; Coffin 1995; Nowak et al. 1997; Stengel 2008). In the simplest interpretation of these models, three drug combinations should be more advantageous than two drug regimens, and in fact, this was the precedent established in early clinical trials of combination antiretroviral therapy. However, this interpretation assumes that all drugs have equal activity, that they require the same number of mutations to engender resistance, and that resistance mutations impact viral replication capacity or viral fitness to a similar degree. Trial and error with early antiretroviral agents helped to establish the basic principles for effective drug combinations in HAART. Since these early days, therapies have evolved, with the introduction of newer drugs with greater potency and higher barriers to the development of resistance. Moreover, some antiretroviral agents have been shown to select for mutations which are either incompatible with or engender hypersensitivity to other antiretroviral drugs, suggesting certain ARVs may offer an advantage with respect to resistance barrier when used in the context of specific combinations (Larder et al. 1995; Kempf et al. 1997; Hsu et al. 1998). Therefore, whether HIV-1 treatment can be simplified to two or even one potent $\operatorname{drug}(\mathrm{s})$ remains an open question that can only be answered with future clinical studies.

In 2010, HIV-1 treatment guidelines in the United States and European Union recommend the initiation of HAART with three fully active antiretroviral agents when CD4 cells in peripheral blood decline to 350 per cubic mm, a stage at which viral levels can often reach 10,000100,000 copies per mL (as measured by RNA in the blood) (see http://aidsinfo.nih.gov/ Guidelines/). With proper adherence, HAART can suppress viral replication for decades, dramatically increasing the life expectancy of the HIV-infected individual. However, HAART alone cannot eliminate HIV-1 infection. HIV-1 is a chronic infection for which there is currently no cure-the prospect of maintaining therapy for the lifetime of a patient presents major challenges. The potential for persistent viral replication in compartments and reservoirs may continue to drive pathogenic disease processes (Finzi et al. 1997, 1999). The effect of therapy can be impaired by nonadherence, poor drug tolerability, and drug interactions among antiretroviral agents and other medications that decrease optimal drug levels. Each of these can lead to virologic failure and the evolution of drug resistance.

For all antiretroviral drug classes, drug resistance has been documented in patients failing therapy as well as in therapy-naïve patients infected with transmitted, drug-resistant viruses. 
Resistance testing is therefore recommended before initiating HAART in therapy-naïve patients as well as when reoptimizing antiretroviral therapy after treatment failure. Given the number of agents and distinct classes of antiretroviral drugs available today, most patients, even those with a history of failure, can be successfully treated. However, as the virus continues to evolve and escape, with even the most effective therapies, new HIV-1 treatments will always be needed.

\section{THE HIV REPLICATION CYCLE AND DRUG TARGETS}

Antiretroviral agents for the treatment of HIV-1 are a relatively new addition to the armamentarium of antiviral drugs. In the 1960s, amantadine and rimantidine were the first approved antiviral drugs for treatment of a human influenza virus infection (Davies et al. 1964; Wingfield et al. 1969), but more than 20 years passed before the elucidation of their mechanism of action (Hay et al. 1985). With the advent of modern molecular biology, such serendipitous approaches to antiviral drug discovery have been largely replaced by mechanistic-based approaches, which include (1) high throughput compound screens with virus-specific replication or enzymatic assays, (2) optimization of inhibitors using lead compounds based on homologous enzymes or targets, and/or (3) rational drug design modeled on the structures of viral proteins. These methods together with advances in the corresponding enabling technologies greatly accelerated the development of antiretroviral drugs in the early 1990s. The highly divergent evolution of HIV-1 genes from the human host provided the basis for implementing targeted screening efforts and/or designing and optimizing inhibitors with minimal off-target activities, thus capitalizing on these technological advances. A full timeline in the development of antiviral and antiretroviral drugs for human use is described in Figure 1.

Whereas the HIV-1 life cycle presents many potential opportunities for therapeutic intervention, only a few have been exploited. The replication scheme of HIV-1 is shown in Figure 2, marked with the steps blocked by approved inhibitors (numbers in panel 2A). A timing of the retroviral lifecycle is described in panel B based on the specific time window of inhibition by a specific drug class. In panel 2C, the inhibitors in development (normal text) or FDA approved (italic/bold text) are listed by inhibition of a specific retroviral replication event. The first step in the HIV-1 replication cycle, viral entry (Doms and Wilen 2011), is the target for several classes of antiretroviral agents: attachment inhibitors, chemokine receptor antagonists, and fusion inhibitors. The HIV-1 envelope gp120/gp41 has affinity for the CD4 receptor and directs HIV-1 to $\mathrm{CD}^{+}{ }^{+}$immune cells (Dalgleish et al. 1984; Klatzmann et al. 1984). Interaction of the gp120 subunit of the HIV-1 envelope with CD4 is followed by binding to an additional coreceptor, either the CC chemokine receptor CCR5 or the CXC chemokine receptor CXCR4 (Alkhatib et al. 1996; Deng et al. 1996; Doranz et al. 1996; Feng et al. 1996). The disposition of these coreceptors on the surface of lymphocytes and monocyte/macrophages, and coreceptor recognition by the viral envelope, are major determinants of tropism for different cell types. These sequential receptor-binding

Figure 2. Identifying distinct steps in HIV-1 life cycle as potential or current target for antiretroviral drugs. $(A)$ Schematic of the HIV-1 life cycle in a susceptible $\mathrm{CD} 4^{+}$cell. $(B)$ Time frame for antiretroviral drug action during a single-cycle HIV-1 replication assay. In this experiment, HIV-1 inhibitors are added following a synchronized inhibition. The addition of drug following the HIV-1 replication step targeted by the drug will result in a lack of inhibition. The time window of drug inhibition provides an estimate for the time required for these replication steps. For example, T30 or enfuvirtide (T20) only inhibits within 1-2 h of infection, whereas lamivudine (3TC) inhibits within a 2- to 10-h time frame, which coincides with reverse transcription. $(C)$ Preclinical, abandoned (normal text), or FDA-approved (bold italic text) inhibitors are listed in relation to specificity of action and drug target. 
$\overbrace{\mathrm{CSH}}^{\infty} \&$ Cold Spring Harbor Perspectives in Medicine

PERSPECTIVS

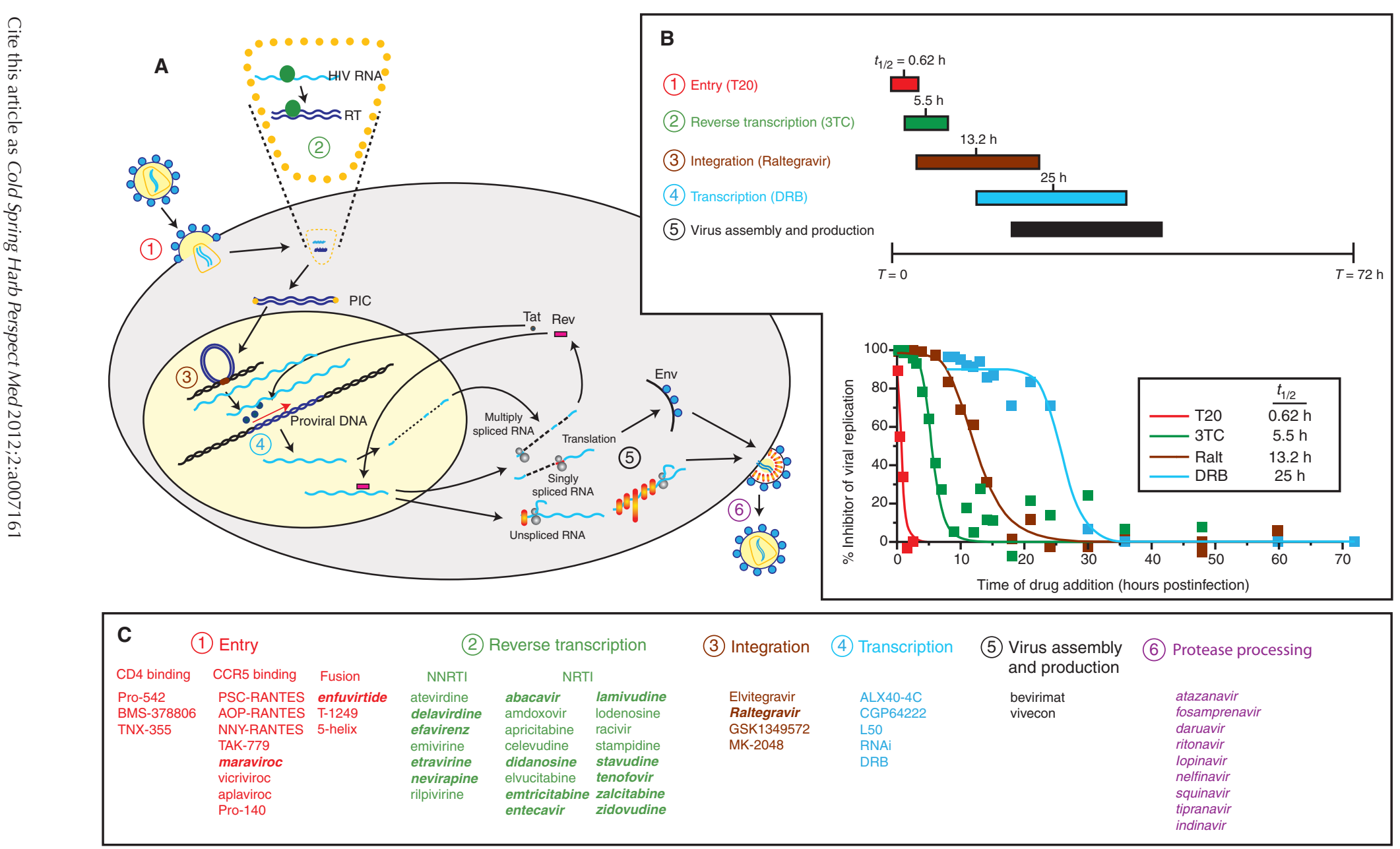

Figure 2. See legend on facing page. 
events trigger conformational changes in the HIV-1 envelope, exposing a hydrophobic domain on gp41 that mediates fusion with the cellular membrane. The entire entry process is completed within $1 \mathrm{~h}$ of virus contact with the cell (Fig. 2B). Gp120 and CD4 are targets for small-molecule and antibody-based attachment inhibitors BMS-378806 and TNX-355, each of which have shown some clinical promise, although neither is approved for use in HIV-1 patients (Reimann et al. 1997; Lin et al. 2003; Kuritzkes et al. 2004). BMS-378806 binds to a pocket on gp120 important for binding CD4 and alters the conformation of the envelope protein such that it cannot recognize CD4 (Lin et al. 2003). TNX-355 is a humanized anti-CD4 monoclonal antibody that binds to CD4 and inhibits HIV-1 envelope docking, but does not inhibit CD4 function in immunological contexts (Reimann et al. 1997). Gp41 and the coreceptor CCR5 are the targets for the two approved entry agents that will be discussed in more detail below: the peptidebased fusion inhibitor, fuzeon, and the smallmolecule CCR5 chemokine receptor antagonist, maraviroc.

Viral entry and fusion of the HIV-1 envelope with the host cell membrane allow for uncoating of the viral core and initiate a slow dissolution process that maintains protection of the viral RNA genome while permitting access to deoxyribonucleoside triphosphates (dNTPs) necessary for reverse transcription and proviral DNA synthesis (Fig. 1). Reverse transcription is a process extending over the next 10 h of infection (Fig. 2A,B). Reverse transcriptase (RT) was the first HIV-1 enzyme to be exploited for antiretroviral drug discovery (Fig. 1). RT is a multifunctional enzyme with RNA-dependent DNA polymerase, RNase-H, and DNA-dependent DNA polymerase activities, all of which are required to convert the single-stranded HIV-1 viral RNA into doublestranded DNA (Hughes and Hu 2011). RT is the target for two distinct classes of antiretroviral agents: the NRTIs (Fig. 2C), which are analogs of native nucleoside substrates, and the NNRTIs (Fig. 2C), which bind to a noncatalytic allosteric pocket on the enzyme. Together, the 12 licensed agents in these two classes account for the nearly half of all approved antiretroviral drugs. Although the NRTIs and NNRTIs differ with respect to their site of interaction on the enzyme and molecular mechanism, both affect the DNA polymerization activity of the enzyme and block the generation of full-length viral DNA.

The completion of reverse transcription is required to form the viral preintegration complex, or PIC. The PIC, comprised of viral as well as cellular components, is transported to the nucleus where the second essential HIV-1 enzyme, integrase, catalyzes the integration of the viral DNA with the host DNA (Craigie and Bushman 2011). Integrase orchestrates three sequence-specific events required for integration, assembly with the viral DNA, endonucleolytic processing of the $3^{\prime}$ ends of the viral DNA, and strand transfer or joining of the viral and cellular DNA. In the context of HIV-1 infection, the process occurs in a stepwise manner, with the rate-limiting event being strand transfer and the stable integration of the viral genome into the human chromosome occurring within the first 15-20 h of infection (Fig. 2B). The newest class of approved ARVs, integrase inhibitors (INIs or InSTIs) (Fig. 2C), specifically inhibit strand transfer and block integration of the HIV-1 DNA into the cellular DNA.

Integration of the HIV-1 DNA is required to maintain the viral DNA in the infected cell and is essential for expression of HIV-1 mRNA and viral RNA. Following integration, the cellular machinery can initiate transcription; however, transcript elongation requires binding of the HIV-1 regulatory protein Tat to the HIV-1 RNA element (TAR) (Karn and Stoltzfus 2011). This mechanism is unique to HIV-1 and is thus considered a highly desirable therapeutic target. A variety of candidate small-molecule inhibitors of either HIV transcription, or more specifically, the Tat-TAR interaction, have been identified during the last 15 yrs (Fig. 2A,C, section 4) (Hsu et al. 1991; Cupelli and Hsu 1995; Hamy et al. 1997; Hwang et al. 2003). Unfortunately, none of these compounds were sufficiently potent and/or selective to progress beyond phase I clinical trials. 
HIV-1 Antiretroviral Drug Therapy

Recent reports describe a new cyclic Tat peptidomimetic that binds to TAR with high affinity and shows broad and potent HIV-1 inhibition (Davidson et al. 2009; Lalonde 2011). Surprisingly, this drug inhibits both HIV-1 reverse transcription and Tat-mediated mRNA transcription (Lalonde 2011).

The assembly and maturation of HIV-1 on the inner plasma membrane is also an active area for drug discovery. Inhibitors such as betulinic acid have been shown to block HIV-1 maturation by interacting with the viral capsid (Fig. 2A,C, section 5) (Fujioka et al. 1994; Li et al. 2003). Although a promising new mechanism of action, insufficient antiviral activity precluded the development beyond early phase clinical trials (Smith et al. 2007).

The context of the HIV-1 life cycle, the final class of approved ARVs, is the HIV-1 PIs. PIs block proteolysis of the viral polyprotein, a step required for the production of infectious viral particles (Sundquist and Kräusslich 2011). PIs are among the most potent agents developed to date, but are large, peptidelike compounds that generally require the coadministration of a "boosting" agent to inhibit their metabolism and enhance drug levels. Therefore, PI-containing regimens contain a fourth drug, albeit one that does not directly contribute to overall antiviral activity. To date, ritonavir (RTV) is the only boosting agent or pharmacokinetic enhancer (PKE) available for use (Kempf et al. 1997; Hsu et al. 1998), although other compounds are in early stages of clinical development.

This description of the HIV-1 replication cycle (Fig. 2) provides a cursory overview of the most advanced antiretroviral drug targets with a focus on the approved agents that will be covered in more detail below. However, it should be noted that nearly all viral processes that are distinct from the cellular life cycle are potentially suitable for screening/designing inhibitors. Enhancing or modulating the activities of cellular restriction factors (Malim and Bieniasz 2011) could also potentially provide an approach to inhibiting HIV-1 replication and/or modulate pathogenesis and transmission, but this topic is not covered further here.

\section{NUCLEOSIDE/NUCLEOTIDE REVERSE TRANSCRIPTASE INHIBITORS}

NRTIs were the first class of drugs to be approved by the FDA (Fig. 1) (Young 1988). NRTIs are administered as prodrugs, which require host cell entry and phosphorylation (Mitsuya et al. 1985; Furman et al. 1986; Mitsuya and Broder 1986; St Clair et al. 1987; Hart et al. 1992) by cellular kinases before enacting an antiviral effect (Fig. 3). Lack of a $3^{\prime}$-hydroxyl group at the sugar ( 2 -deoxyribosyl) moiety of the NRTIs prevents the formation of a $3^{\prime}-5^{\prime}$-phosphodiester bond between the NRTIs and incoming $5^{\prime}$-nucleoside triphosphates, resulting in termination of the growing viral DNA chain. Chain termination can occur during RNA-dependent DNA or DNA-dependent DNA synthesis, inhibiting production of either the $(-)$ or $(+)$ strands of the HIV-1 proviral DNA (Cheng et al. 1987; Balzarini et al. 1989; Richman 2001). Currently, there are eight FDA-approved NRTIs: abacavir (ABC, Ziagen), didanosine (ddI, Videx), emtricitabine (FTC, Emtriva), lamivudine (3TC, Epivir), stavudine (d4T, Zerit), zalcitabine (ddC, Hivid), zidovudine (AZT, Retrovir), and Tenofovir disoprovil fumarate (TDF, Viread), a nucleotide RT inhibitor (Fig. 3).

As with all antiretroviral therapies, treatment with any of these agents often results in the emergence of HIV-1 strains with reduced drug susceptibility. Resistance to NRTIs is mediated by two mechanisms: ATP-dependent pyrophosphorolysis, which is the removal of NRTIs from the $3^{\prime}$ end of the nascent chain, and reversal of chain termination (Arion et al. 1998; Meyer et al. 1999; Boyer et al. 2001) and increased discrimination between the native deoxyribonucleotide substrate and the inhibitor. NRTI mutations occur in RT and are classified as nucleoside/nucleotide associated mutations (NAMs) or thymidine analog mutations (TAMs). TAMs promote pyrophosphorolysis and are involved in the excision of AZT and d4T (Arion et al. 1998; Meyer et al. 2002; Naeger et al. 2002). TAM amino acid changes in HIV-1 RT include two distinct pathways: the TAM1 pathway (M41L, L210W, T215Y, 


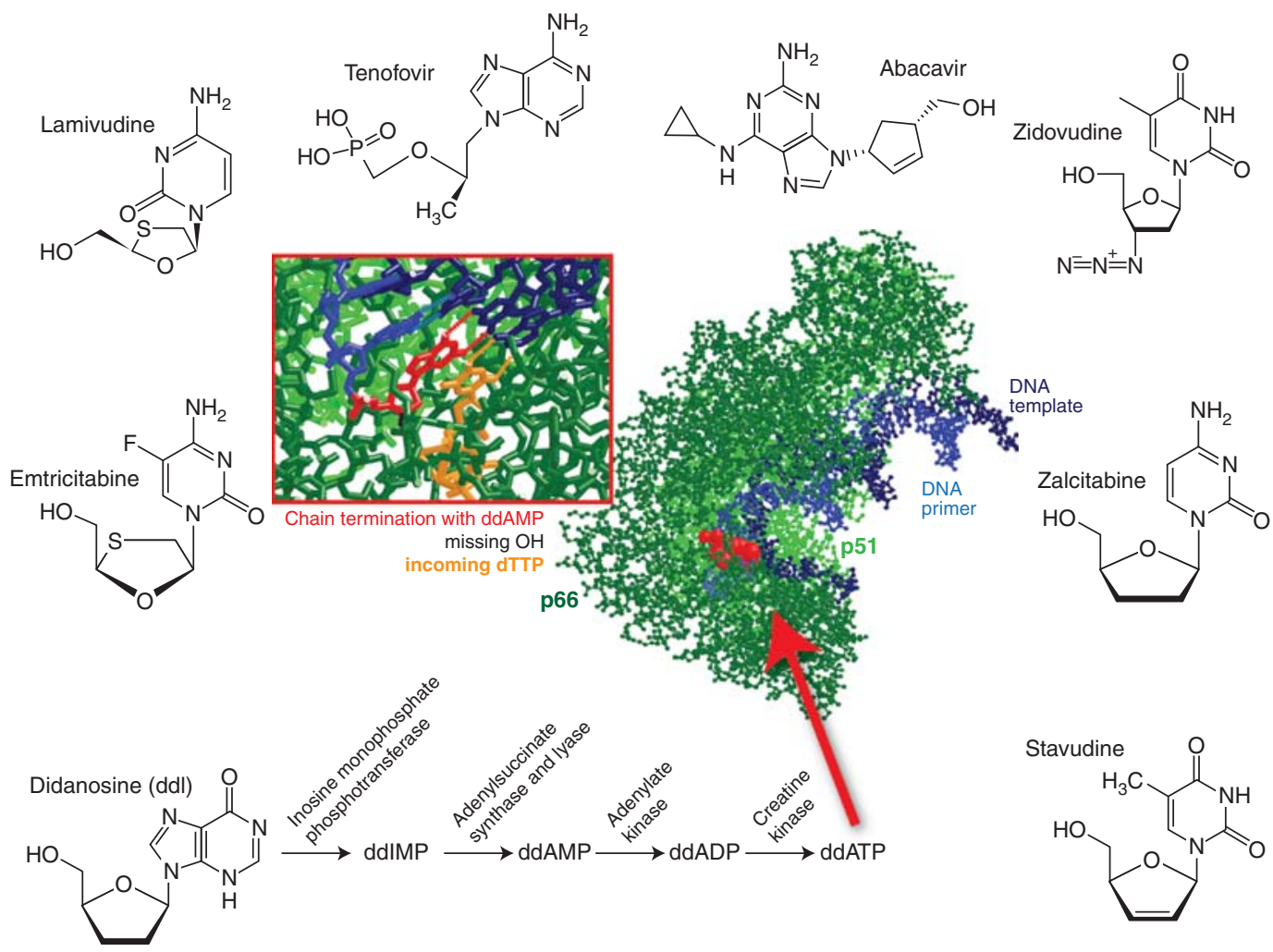

Figure 3. Nucleos(t)ide reverse transcriptase inhibitors and X-ray crystal structure of HIV-1 RT in complex with DNA primer/template chain terminated with ddAMP and with an incoming dTTP. The cartoon of the crystal structure data was adapted from coordinates deposited by Huang et al. (1998) (1RTD).

and occasionally $\mathrm{D} 67 \mathrm{~N})$ and the TAM2 pathway (D67N, K70R, T215F, and 219E/Q) (Larder and Kemp 1989; Boucher et al. 1992; Kellam et al. 1992; Harrigan et al. 1996; Bacheler et al. 2001; Marcelin et al. 2004; Yahi et al. 2005).

A second mechanism of NRTI resistance is the prevention of NRTI incorporation into the nascent chain. Mutations associated with this mechanism include the $\mathrm{M} 184 \mathrm{~V} / \mathrm{I}$ and the K65R. The M184V mutation emerges with 3TC or FTC therapy (Schinazi et al. 1993; Quan et al. 1996), whereas treatment with Tenofovir, ddC, ddI, d4T, and ABC can select K65R (Wainberg et al. 1999; Margot et al. 2002; Garcia-Lerma et al. 2003; Shehu-Xhilaga et al. 2005). In general, K65R rarely emerges in patients receiving any AZT-containing regimen because this mutation is phenotypically antagonistic to the TAMs (Parikh et al. 2006;
White et al. 2006). M184V restores Tenofovir susceptibility in the presence of K65R (Deval et al. 2004), thus K65R viruses are also infrequent in patients on Tenofivir who fail 3TC or emtricitabine (FTC) with M184V.

Many primary and secondary NRTI mutations (or combinations of these) have been shown to decrease RT function and viral replicative fitness (Quinones-Mateu and Arts 2002, 2006). Although several studies have suggested a potential for a clinical benefit associated with reduced replicative fitness of NRTI-resistant variants, it is important to note that additional mutations can accumulate in the presence of ongoing treatment resulting in higher levels of resistance. The loss in replicative fitness owing to drug resistance mutations (in the absence of drug) can also be compensated by accumulating secondary mutations. 


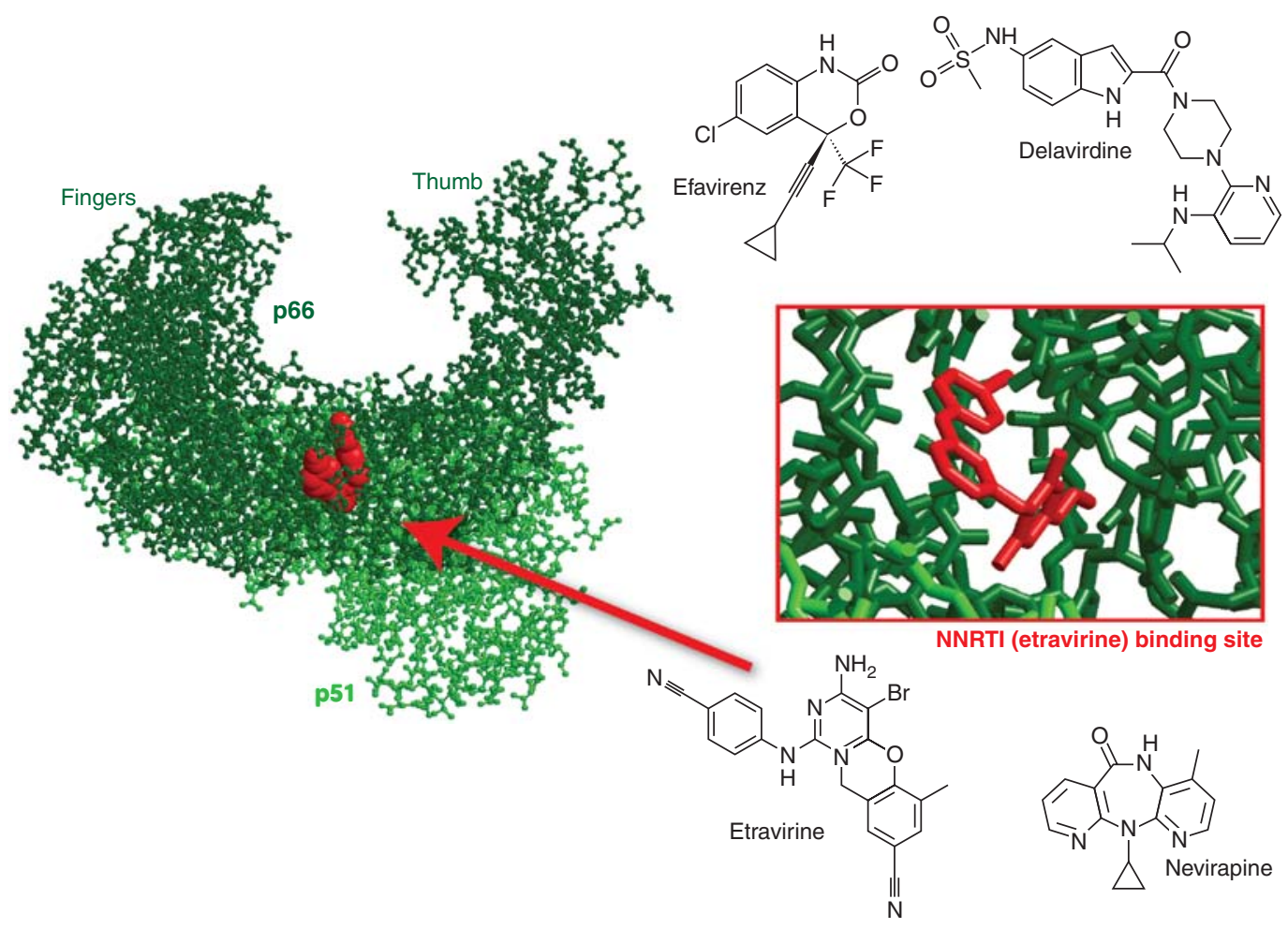

Figure 4. Non-nucleoside RT inhibitors and the X-ray crystal structure of HIV-1 RT complexed with etravirine (Lansdon et al. 2010) (3MEE).

\section{NON-NUCLEOSIDE REVERSE TRANSCRIPTASE INHIBITORS}

NNRTIs inhibit HIV-1 RT by binding and inducing the formation of a hydrophobic pocket proximal to, but not overlapping the active site (Fig. 4) (Kohlstaedt et al. 1992; Tantillo et al. 1994). The binding of NNRTIs changes the spatial conformation of the substrate-binding site and reduces polymerase activity (Kohlstaedt et al. 1992; Spence et al. 1995). The NNRTI-binding pocket only exists in the presence of NNRTIs (Rodgers et al. 1995; Hsiou et al. 1996) and consists of hydrophobic residues (Y181, Y188, F227, W229, and Y232), and hydrophilic residues such as K101, K103, S105, D192, and E224 of the p66 subunit and E138 of the p51 subunit (Fig. 4) (Sluis-Cremer et al. 2004). Unlike NRTIs, these non/uncompetitive inhibitors do not inhibit the RT of other lentiviruses such as HIV-2 and simian immunodeficiency virus (SIV) (Kohlstaedt et al. 1992; Witvrouw et al. 1999). Currently, there are four approved NNRTIs: etravirine, delavirdine, efavirenz, and nevirapine, and several in development, including rilpivirine in phase 3 (Fig. 4).

NNRTI resistance generally results from amino acid substitutions such as L100, K101, K103, E138, V179, Y181, and Y188 in the NNRTI-binding pocket of RT (Tantillo et al. 1994). The most common NNRTI mutations are $\mathrm{K} 103 \mathrm{~N}$ and Y181C (Bacheler et al. 2000, 2001; Demeter et al. 2000; Dykes et al. 2001). As with NRTI resistance, complex patterns of NNRTI-resistant mutations can arise and alternative pathways have been observed in nonsubtype B infected individuals (Brenner et al. 2003; Spira et al. 2003; Gao et al. 2004). Most NNRTI mutations engender some level of cross resistance among different NNRTIs, especially in the context of additional secondary mutations (Antinori et al. 2002). 
In contrast to the significant reductions in replicative fitness observed with resistance to other drug classes, with NNRTIs, single nucleotide changes can result in high-level resistance with only a slight loss of replicative fitness (Deeks 2001; Dykes et al. 2001; Imamichi et al. 2001). A lower genetic barrier, minimal impact on replicative fitness, and the slow reversion of these mutations in patients in the absence of drug contribute to transmission and stability of NNRTI-resistant HIV-1 in the population. Interestingly, the majority of NNRTI-resistance mutations selected under NNRTI treatment are commonly found as wildtype sequence in HIV-1 group $\mathrm{O}$ and HIV-2. HIV-1 group $\mathrm{O}$ can actually be subdivided into lineages based on a C181 or Y181 amino acid in RT (Tebit et al. 2010). Furthermore, nearly all primate lentiviruses can be phylogenetically classified into different lineages based on signature sequences in NNRTI-binding pocket and linked to a Cys, Ile, or Tyr at position 181, i.e., the primary codon-conferring resistance to NNRTIs (Tebit et al. 2010). Given the intrinsic resistance in most primate lentiviruses, aside from HIV-1 group $\mathrm{M}$, it is not surprising that acquired resistance to NNRTIs has the least fitness impact.

\section{INTEGRASE INHIBITORS}

Integrase was the most recent HIV-1 enzyme to be successfully targeted for drug development (Espeseth et al. 2000; Hazuda et al. 2004a,b). Raltegravir (RAL), MK-0518 was FDA approved in 2007, and other integrase inhibitors, including Elvitegravir (EVG), GS-9137 are progressing through clinical development (Fig. 5) (Sato et al. 2006; Shimura et al. 2008). As mentioned above, integrase catalyzes $3^{\prime}$ end processing and viral DNA and strand transfer. All integrase inhibitors in development target the strand transfer reaction and are thus referred to as either INIs or more specifically, integrase strand transfer inhibitors (InSTIs) (Espeseth et al. 2000; Hazuda et al. 2004a,b; McColl and Chen 2010). The selective effect on strand transfer is a result of a now well-defined mechanism of action in which the inhibitor (1) binds only to the specific complex between integrase and the viral DNA and (2) interacts with the two essential magnesium metal ion cofactors in the integrase active site and also the DNA (Fig. 5). Therefore, all InSTIs are comprised of two essential components: a metal-binding pharmacophore, which sequestors the active site magnesiums, and a hydrophobic group, which interacts with the viral DNA as well as the enzyme in the complex (Grobler et al. 2002). InSTIs are therefore the only ARV class that interacts with two essential elements of the virus, the integrase enzyme as well as the viral DNA, which is the substrate for integration.

The recent cocrystallization of the foamy virus integrase DNA complex or intasome with both RAL and EVG (Hare et al. 2010) corroborates the biochemical mechanism and provides a structural basis for understanding the unique breadth of antiviral activity that has been observed for InSTIs across all HIV-1 subtypes as well as other retroviruses, such as HIV-2 and XMRV (Fig. 5) (Maignan et al. 1998; Damond et al. 2008; Shimura et al. 2008; Van Baelen et al. 2008; Garrido et al. 2010; Singh et al. 2010). In the cocrystal structure, the general architecture and amino acids within the active site of the foamy virus intasome are highly conserved with other retroviral integrases, as are the immediate surrounding interactions with InSTIs. The common mechanism of action and conserved binding mode for InSTIs also has important implications for understanding resistance to the class. Mutations that engender resistance to InSTIs almost always map within the integrase active site near the amino acid residues that coordinate the essential magnesium cofactors (Hazuda et al. 2004a; Hare et al. 2010). Thus, these mutations have deleterious effects on enzymatic function and viral replicative capacity (Marinello et al. 2008; Quercia et al. 2009). In clinical studies, resistance to Raltegravir is associated with three independent pathways or sets of mutations in the integrase gene, as defined by primary or signature mutations at Y143, N155, or Q148 (Fransen et al. 2009). These primary mutations are generally observed with specific secondary mutations; for $\mathrm{N} 155(\mathrm{H})$ these include E92Q, 
$\overbrace{\mathrm{CSH}}^{\infty} \mathrm{\&}$ Cold Spring Harbor Perspectives in Medicine

PERSPECTNES

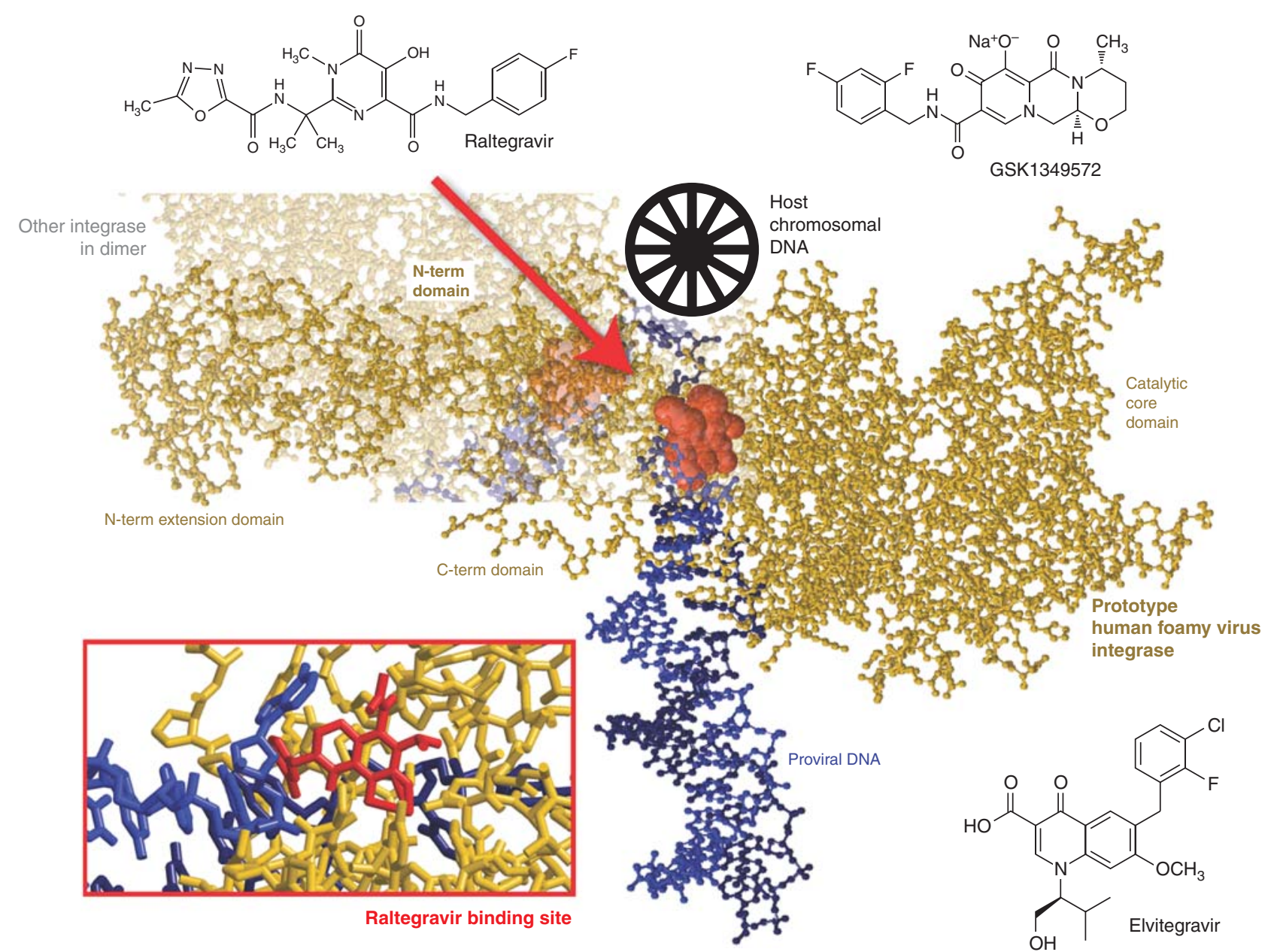

Figure 5. Integrase strand transfer inhibitors and the crystal structure of prototype human foamy virus integrase (as a model of 
V151L, T97A, G163R, and L74M, whereas for Q148(K/R/H), G140S/A and E138K are common. Significant cross resistance is observed among the InSTIs almost regardless of the primary/secondary mutation sets (Goethals et al. 2008; Marinello et al. 2008). Although cross resistance is prevalent, different agents appear to preferentially select different patterns of mutations (Hazuda et al. 2004a).

\section{PROTEASE INHIBITORS}

The HIV-1 protease is the enzyme responsible for the cleavage of the viral gag and gag-pol polyprotein precursors during virion maturation (Park and Morrow 1993; Miller 2001). Ten PIs are currently approved: amprenavir (APV, Agenerase), atazanavir (ATZ, Reyataz), darunavir (TMC114, Prezista), fosamprenavir (Lexiva), indinavir (IDV, Crixivan), lopinavir (LPV), nelfinavir (NFV, Viracept), ritonavir (RTV, Norvir), saquinavir (SQV, Fortovase/ Invirase), and tipranavir (TPV, Aptivus) (Fig. 6).

Because of its vital role in the life cycle of HIV-1 and relatively small size $(11 \mathrm{kDa})$, it was initially expected that resistance to protease inhibitors would be rare. However, the protease gene has great plasticity, with polymorphisms observed in 49 of the 99 codons, and more than 20 substitutions known to be associated with resistance (Shafer et al. 2000). The emergence of protease inhibitor resistance likely requires the stepwise accumulation of primary and compensatory mutations (Molla et al. 1996a) and each PI usually selects for certain signature primary mutations and a characteristic pattern of compensatory mutations. Unlike NNRTIs, primary drug-resistant substitutions are rarely observed in the viral populations in protease inhibitor-naïve individuals (Kozal et al. 1996).

All PIs share relatively similar chemical structures (Fig. 6) and cross resistance is commonly observed. For most PIs, primary resistance mutations cluster near the active site of the enzyme, at positions located at the substrate/inhibitor binding site (e.g., D30N, G48V, I50V, V82A, or I84V, among others). These amino acid changes usually have a deleterious effect on the replicative fitness (Nijhuis et al. 2001; Quinones-Mateu and Arts 2002; Quinones-Mateu et al. 2008). In addition to mutations in the protease gene, changes located within eight major protease cleavage sites (i.e., gag and pol genes), have been associated with resistance to protease inhibitors (Doyon et al. 1996; Zhang et al. 1997; Clavel et al. 2000; Miller 2001; Nijhuis et al. 2001). Cleavage site mutants are better substrates for the mutated protease, and thus partially compensate for the resistance-associated loss of viral fitness (Doyon et al. 1996; Mammano et al. 1998; Zennou et al. 1998; Clavel et al. 2000; Nijhuis et al. 2001). With PI resistance, HIV-1 appears to follows a "stepwise" pathway to overcome drug selection: (1) acquisition of primary resistance mutations in the protease gene, (2) selection of secondary/compensatory protease mutations to repair the enzymatic function and rescue viral fitness, and (3) selection of mutations in the major cleavage sites of the gag and gag-pol polyprotein precursors that restore protein processing and increase production of the HIV-1 protease itself (Condra et al. 1995; Molla et al. 1996b; Doyon et al. 1998; Berkhout 1999; Nijhuis et al. 2001).

\section{ENTRY INHIBITORS}

HIV-1 entry exploits several host proteins for a set of intricate events leading to membrane fusion and virus core release into the cytoplasm (Fig. 7). HIV-1 entry inhibitors can be subdivided into distinct classes based on disruption/inhibition of distinct targets/steps in the process.

\section{Fusion Inhibitors}

The crystal structure of the gp41 ectodomain and of the ectodomain partnered with an inhibitory peptide (C34) revealed that the fusionactive conformation of gp41 was a six-helix bundle in which three $\mathrm{N}$ helices form an interior, trimeric coiled coil onto which three antiparallel C helices pack (Doms and Wilen 2011). Peptide fusion inhibitors were designed based on the discovery that two homologous domains 
$8_{\mathrm{CSH}}^{\infty} \mathrm{C}$ Cold Spring Harbor Perspectives in Medicine

PERPECTIES www.perspectivesinmedicine.org

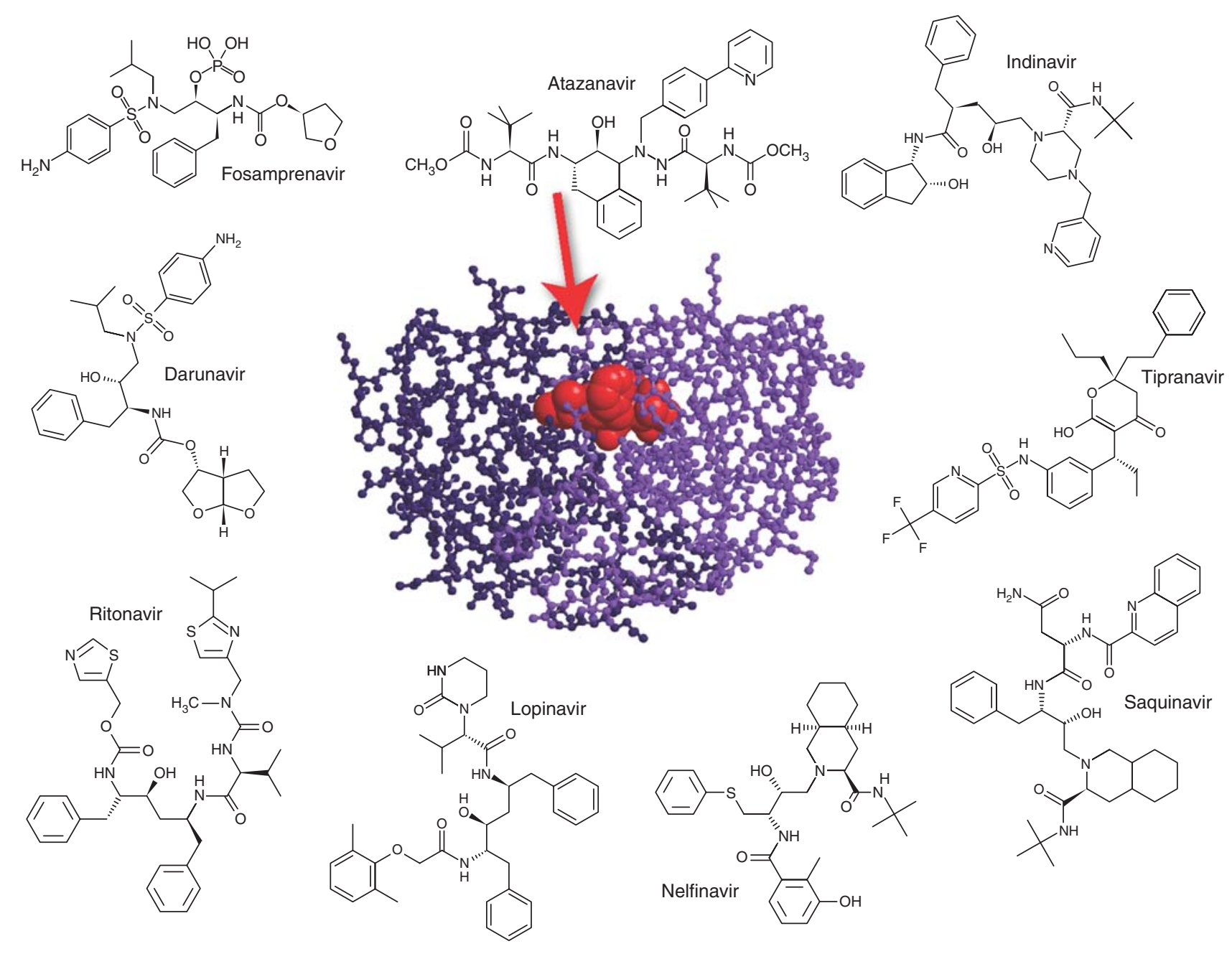

Figure 6. Protease inhibitors and the crystal structure of HIV-1 protease complexed with atazanavir (CA Schiffer, unpubl.) (3EKY). 


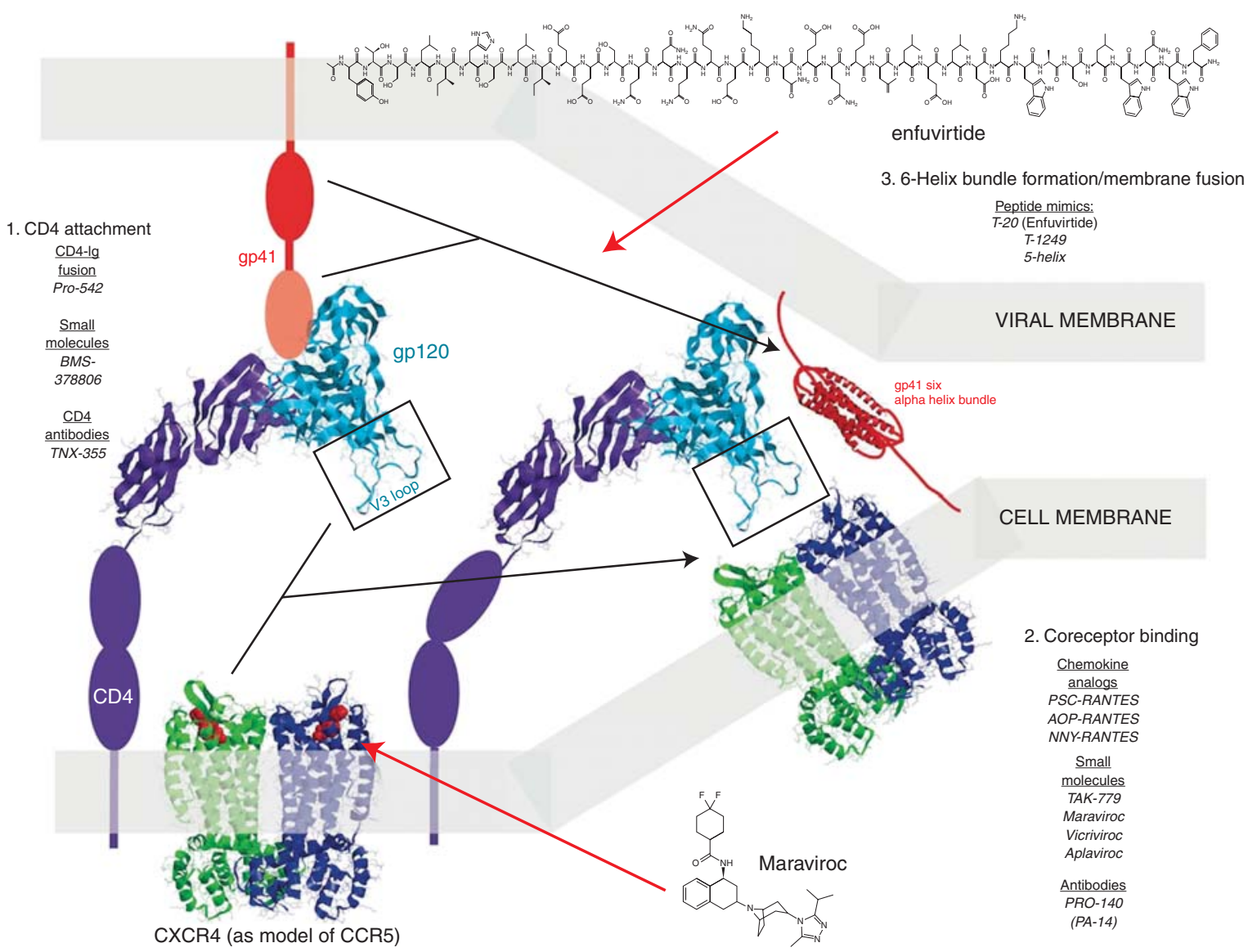

Figure 7. Structure predictions of various viral-host components involved in the HIV-1 entry process and the inhibitors. Section 1 describes the components involved for initial CD4 attachment, specifically the D1 domain of CD4 and the C4 domain of gp 120. The gp120 structure is shown as an overlay of two structures (2NY2 and 3HI1) (Zhou et al. 2007; Chen et al. 2009). Inhibitors of this CD4 process are listed. Interactions between gp 120 and CXCR4 are described in section 2. A rough model of maraviroc (MVC) binding to CCR5 in Figure 7 is based on data from a recently published structure of CXCR4 complexed to a small molecule, IT1t (Wu et al. 2010). The final step in the entry process involves the formation of the gp41 six alpha-helix bundle, which can be blocked by T20 (enfuvirtide). The structure for HIV-1 gp41 six alpha-helix bundle is based on that of SIV gp41 (Malashkevich et al. 1998) (2SIV). 
in the viral gp41 protein must interact with each other to promote fusion, and that mimicry of one of these domains by a heterologous protein can bind and disrupt the intramolecular interactions of the virus protein. Alpha-helical peptides homologous to the leucine zipper domain of gp41 had significant antiviral activity against HIV-1, and this activity depended on their ordered solution structure (Wild et al. 1993, 1994). Rational design of helical inhibitors ultimately produced a molecule (T-20, enfuvirtide) with potent antiviral activity in vivo (Fig. 7) (Kilby et al. 1998; Lalezari et al. 2003).

Resistance to early alpha-helical inhibitors was shown to be mediated by mutations in the amino-terminal heptad repeat region of gp41 (Rimsky et al. 1998), which provide further evidence for binding of these peptides to the virus. Monotherapy with enfuvirtide resulted in viral load rebounds after 14 days with resistance which mapped to determinants in the HR1 domain (G36D, I37T, V38A, V38M, N42T, N42D, N43K) (Wei et al. 2002). Mutations that confer resistance to enfuvirtide result in reduced replication capacity/replicative fitness presumably because mutations that reduce enfuvirtide binding also reduce the efficiency of six-helix bundle formation and overall fusion rates (Reeves et al. 2004, 2005). These mutations do not confer cross resistance to other entry inhibitors (attachment inhibitors or coreceptor inhibitors) (Ray et al. 2005) but can sensitize viruses to neutralization by monoclonal antibodies that target the gp41 domain by prolonging the exposure of fusion intermediates that are specifically sensitive to these antibodies (Reeves et al. 2005). Adaptation to enfuvirtide has even resulted in viruses that require enfuvirtide for fusion (Baldwin et al. 2004).

Resistance mutations in gp41 decrease fusion efficiency and reduce viral fitness (Labrosse et al. 2003). Nonetheless, studies of baseline susceptibility to enfuvirtide suggested that large variations in intrinsic susceptibility existed in diverse HIV-1 isolates, and that these variations mapped to regions outside the enfuvirtidebinding site (Derdeyn et al. 2000). Sequences associated with the V3 loop were correlated with intrinsic enfuvirtide susceptibility, suggesting that interactions with the coreceptor were important determinants of susceptibility of a drug that inhibits virus fusion. A seminal observation in the understanding of entry inhibitor susceptibility was the discovery that efficiency of the fusion process was the principal modulator of intrinsic enfuvirtide susceptibility (Reeves et al. 2002). Mutations in the coreceptorbinding site that reduced gp120 affinity for CCR5 resulted in viruses with reduced fusion kinetics (Reeves et al. 2004; Biscone et al. 2006). Engagement of CD4 by gp120 initiates a process of structural rearrangement in the envelope glycoprotein resulting in fusion. Completion of this process requires engagement of the coreceptor molecule, but enfuvirtide susceptibility is limited to the time between CD4 engagement and six-helix bundle formation. Any decrease in the rate of this entry process (e.g., reducing the levels of coreceptor expression) also increases susceptibility of the virus to inhibition by enfuvirtide. Consistent with this, ENF is synergistic with compounds that inhibit CD4 or coreceptor engagement (Tremblay et al. 2000; Nagashima et al. 2001).

\section{Small-Molecule CCR5 Antagonists}

Small-molecule CCR5 antagonists bind to hydrophobic pockets within the transmembrane helices of CCR5 (Dragic et al. 2000; Tsamis et al. 2003). This site does not overlap the binding sites of either CCR5 agonists or HIV-1 envelope. Instead, drug binding induces and stabilizes a receptor conformation that is not recognized by either. Thus, these molecules are considered allosteric inhibitors. Ideally, a small-molecule inhibitor of CCR5 would block binding by HIV-1 envelope but continue to bind native chemokines and allow signal transduction. Most small-molecule inhibitors, however, are pure antagonists of the receptor. Oral administration of small-molecule antagonists has been shown to inhibit viral replication in macaque models (Veazey et al. 2003) and to prevent vaginal transmission (Veazey et al. 2005). Thus far, three antagonists (VCV, MVC, and Aplaviroc) have been shown to inhibit virus replication in humans (Dorr et al. 2005). The 
compound MVC was approved for therapeutic use by the FDA in 2007 (Fig. 7).

MVC binds a hydrophobic transmembrane cavity of CCR5. Binding alters the conformation of the second extracellular loop of the receptor and prevents interaction with the V3 stem loop of gp120 (Dragic et al. 2000; Kondru et al. 2008). A rough model of MVC binding to CCR5 in Figure 7 is based on a recently published structure of CXCR4 complexed to a small molecule, IT1t (Wu et al. 2010). CXCR4 also serves as a coreceptor for HIV-1 but attempts at development of CXCR4 antagonists (e.g., AMD3100) fail in clinical studies (Hendrix et al. 2004). Because MVC binds to a host cell protein, resistance to MVC is unlike that of other ARVs. Potential resistance mechanisms include (1) tropism switching (utilization of CXCR4 instead of CCR5 for entry), (2) increased affinity for the coreceptor, (3) utilization of inhibitor-bound receptor for entry, and (4) faster rate of entry. Tropism switching has been a concern in the therapeutic administration of this class as primary infection with, or early emergence of CXCR4 tropic virus, although rare, typically leads to faster disease progression. Thus, the selection of CXCR4 tropic virus owing to CCR5 antagonist treatment could have a negative impact on HIV-1 pathogenesis.

Small-molecule CCR5 inhibitors have been used to select for drug resistance in peripheral blood mononuclear cell cultures (PBMC), which express CCR5 and CXCR4, as well as a variety of other chemokine receptors that could potentially substitute for HIV-1 coreceptors. In these experiments, inhibitor-resistant viruses continue to require CCR5 for entry (Trkola et al. 2002; Marozsan et al. 2005; Baba et al. 2007; Westby et al. 2007). Furthermore, evaluation of coreceptor tropism of viruses from patients who failed MVC therapy during clinical trials has suggested that tropism change occurred only when $\mathrm{X} 4$ tropic viruses were preexisting in the patient quasispecies before initiating treatment with MVC (Westby et al. 2006). Thus, it appears that de novo mutations conferring altered coreceptor usage is not the favored pathway for resistance in vitro or in vivo. It should be noted that in some treatment failures, the use of CCR5 was maintained even in the presence of MVC. These "resistant" HIV-1 isolates did not display the same shift in drug susceptibility, typically characterized by an increase in $\mathrm{IC}_{50}$ values, but were capable of using both the free and inhibitor-bound CCR5 for entry (Trkola et al. 2002; Tsibris et al. 2008). In such cases, resistance is reported as MPI (or maximum percent inhibition) for saturating concentrations of drug.

Although it is still early with respect to the clinical experience for CCR5 antagonists, there are documented cases of treatment failures that are not accounted for by either CXCR4 tropism switch or resistance owing to increased MPI. Recent studies suggest discrepancies in the sensitivity to CCR5 antagonists may be assay dependent. Susceptibility to entry CCR5 antagonists can be affected by cell type, state of cellular activation, and number of virus replication cycles (Kuhmann et al. 2004; Marozsan et al. 2005; Lobritz et al. 2007; Westby et al. 2007). Also, different primary HIV-1 isolates can vary in sensitivity by as much as 100 -fold in $\mathrm{IC}_{50}$ values (Torre et al. 2000; Dorr et al. 2005; Lobritz et al. 2007), and this difference is much more demonstrable with infection assays using replication-competent primary $\mathrm{HIV}-1$ isolates as compared with defective viruses limited to single-cycle replication. These complexities make it quite challenging to detect resistance at the time of treatment failure with routine resistance testing assays. Given the issues, the use of CCR5 antagonists in clinical practice is somewhat more complex than other classes of ARV agents.

\section{CONCLUSIONS}

The breadth and depth of the HIV-1 therapy pipeline may arguably be among the most successful for treating any single human disease, infection, or disorder as illustrated by the number of antiretroviral agents and unique drug classes available. In reviewing the history of ARV drug development, however, there are some key lessons and parallels that need to be kept in mind as we consider the development 
of small-molecule prevention strategies for HIV-1 and evolving treatment strategies for other viral infections, including hepatitis $\mathrm{C}$ virus (HCV). The road to successful HIV-1 treatment was hard, and in the early days many patients were inadequately treated with suboptimal regimens that rapidly led to failure and drug resistance. Although it is unknown whether the prevention of $\mathrm{HIV}-1$ transmission will require the same number of agents, the inherent plasticity of HIV-1 would suggest erring on the side of caution and focusing early on combination products that would mitigate this risk. In the case of $\mathrm{HCV}$, the breadth of genetic diversity appears to be greater than that observed in an HIV-1 infected individual. Anti-HCV drugs in the most advanced stages for approval inhibit a small number of targets (e.g., the NS5b polymerase and NS3 protease) and each class appears to share significant cross resistance; when tested as single agents, the emergence of HCV drug resistance is rapid. The success of HAART should provide the benchmark for HCV drug development and a roadmap for the development of novel prevention strategies in HIV-1 to avoid potential risk to both the individual patient and the population by preventing the acquisition and transmission of drug resistance.

\section{REFERENCES}

* Reference is also in this collection.

Abram ME, Ferris AL, Shao W, Alvord WG, Hughes SH. 2010. Nature, position, and frequency of mutations made in a single cycle of HIV-1 replication. J Virol 84: 9864-9878.

Alkhatib G, Combadiere C, Broder CC, Feng Y, Kennedy PE, Murphy PM, Berger EA. 1996. CC CKR5: A RANTES, MIP-1a, MIP-1b receptor as a fusion cofactor for macrophage-tropic HIV-1. Science 272: 1955-1958.

Antinori A, Zaccarelli M, Cingolani A, Forbici F, Rizzo MG, Trotta MP, Di Giambenedetto S, Narciso P, Ammassari A, Girardi E, et al. 2002. Cross-resistance among nonnucleoside reverse transcriptase inhibitors limits recycling efavirenz after nevirapine failure. AIDS Res Hum Retroviruses 18: 835-838.

Arion D, Kaushik N, McCormick S, Borkow G, Parniak MA. 1998. Phenotypic mechanism of HIV-1 resistance to $3^{\prime}$-azido-3'-deoxythymidine (AZT): Increased polymerization processivity and enhanced sensitivity to pyrophosphate of the mutant viral reverse transcriptase. Biochemistry 37: 15908-15917.
Autran B, Carcelain G, Li TS, Blanc C, Mathez D, Tubiana R, Katlama C, Debre P, Leibowitch J. 1997. Positive effects of combined antiretroviral therapy on $\mathrm{CD} 4^{+} \mathrm{T}$ cell homeostasis and function in advanced HIV disease. Science 277: 112-116.

Baba M, Miyake H, Wang X, Okamoto M, Takashima K. 2007. Isolation and characterization of human immunodeficiency virus type 1 resistant to the small-molecule CCR5 antagonist TAK-652. Antimicrob Agents Chemother 51: 707-715.

Bacheler LT, Anton ED, Kudish P, Baker D, Bunville J, Krakowski K, Bolling L, Aujay M, Wang XV, Ellis D, et al. 2000. Human immunodeficiency virus type 1 mutations selected in patients failing efavirenz combination therapy. Antimicrob Agents Chemother 44: 2475-2484.

Bacheler L, Jeffrey S, Hanna G, D'Aquila R, Wallace L, Logue K, Cordova B, Hertogs K, Larder B, Buckery R, et al. 2001. Genotypic correlates of phenotypic resistance to efavirenz in virus isolates from patients failing nonnucleoside reverse transcriptase inhibitor therapy. J Virol 75: 4999-5008.

Baldwin CE, Sanders RW, Deng Y, Jurriaans S, Lange JM, Lu M, Berkhout B. 2004. Emergence of a drug-dependent human immunodeficiency virus type 1 variant during therapy with the T20 fusion inhibitor. $J$ Virol 78: 12428-12437.

Balzarini J, Herdewijn P, De Clercq E. 1989. Differential patterns of intracellular metabolism of $2^{\prime}, 3^{\prime}$-didehydro$2^{\prime}, 3^{\prime}$-dideoxythymidine and $3^{\prime}$-azido- $2^{\prime}, 3^{\prime}$-dideoxythymidine, two potent anti-human immunodeficiency virus compounds. J Biol Chem 264: 6127-6133.

Berkhout B. 1999. HIV-1 evolution under pressure of protease inhibitors: Climbing the stairs of viral fitness. $J$ Biomed Sci 6: 298-305.

Biscone MJ, Miamidian JL, Muchiri JM, Baik SS, Lee FH, Doms RW, Reeves JD. 2006. Functional impact of HIV coreceptor-binding site mutations. Virology 351: 226-236.

Boucher CA, O'Sullivan E, Mulder JW, Ramautarsing C, Kellam P, Darby G, Lange JM, Goudsmit J, Larder BA. 1992. Ordered appearance of zidovudine resistance mutations during treatment of 18 human immunodeficiency virus-positive subjects. J Infect Dis 165: 105-110.

Boyer PL, Sarafianos SG, Arnold E, Hughes SH. 2001 Selective excision of AZTMP by drug-resistant human immunodeficiency virus reverse transcriptase. J Virol 75: 4832-4842.

Brenner B, Turner D, Oliveira M, Moisi D, Detorio M, Carobene M, Marlink RG, Schapiro J, Roger M, Wainberg MA. 2003. AV106M mutation in HIV-1 clade C viruses exposed to efavirenz confers cross-resistance to nonnucleoside reverse transcriptase inhibitors. AIDS 17: F1-F5.

Chen L, Kwon YD, Zhou T, Wu X, O'Dell S, Cavacini L, Hessell AJ, Pancera M, Tang M, Xu L, et al. 2009. Structural basis of immune evasion at the site of CD4 attachment on HIV-1 gp120. Science 326: 1123-1127.

Cheng YC, Dutschman GE, Bastow KF, Sarngadharan MG, Ting RY. 1987. Human immunodeficiency virus reverse transcriptase. General properties and its interactions with nucleoside triphosphate analogs. J Mol Biol 262: 2187-2189. 
E.J. Arts and D.J. Hazuda

Clavel F, Race E, Mammano F. 2000. HIV drug resistance and viral fitness. Adv Pharmacol 49: 41-66.

Coffin JM. 1995. HIV population dynamics in vivo: Implications for genetic variation, pathogenesis, and therapy. Science 267: 483-489.

Collier AC, Coombs RW, Schoenfeld DA, Bassett RL, Timpone J, Baruch A, Jones M, Facey K, Whitacre C, McAuliffe VJ, et al. 1996. Treatment of human immunodeficiency virus infection with saquinavir, zidovudine, and zalcitabine. AIDS Clinical Trials Group. $N$ Engl J Med 334: 1011-1017.

Condra JH, Schleif WA, Blahy OM, Gabryelski LJ, Graham DJ, Quintero JC, Rhodes A, Robbins HL, Roth E, Shivaprakash M. 1995. In vivo emergence of HIV-1 variants resistant to multiple protease inhibitors. Nature (London) 374: $569-571$.

* Craigie R, Bushman FD. 2011. HIV DNA integration. Cold Spring Harb Perspect Med doi: 10.1101/cshperspect. a006890.

Cupelli LA, Hsu MC. 1995. The human immunodeficiency virus type 1 Tat antagonist, Ro 5-3335, predominantly inhibits transcription initiation from the viral promoter J Virol 69: 2640-2643

D'Aquila RT, Hughes MD, Johnson VA, Fischl MA, Sommadossi JP, Liou SH, Timpone J, Myers M, Basgoz N, Niu M, et al. 1996. Nevirapine, zidovudine, and didanosine compared with zidovudine and didanosine in patients with HIV-1 infection. A randomized, double-blind, placebocontrolled trial. National Institute of Allergy and Infectious Diseases AIDS Clinical Trials Group Protocol 241 Investigators. Ann Intern Med 124: 1019-1030.

Dalgleish AG, Beverley PC, Clapham PR, Crawford DH, Greaves MF, Weiss RA. 1984. The CD4 (T4) antigen is an essential component of the receptor for the AIDS retrovirus. Nature 312: 763-767.

Damond F, Lariven S, Roquebert B, Males S, Peytavin G, Morau G, Toledano D, Descamps D, Brun-Vezinet F Matheron S. 2008. Virological and immunological response to HAART regimen containing integrase inhibitors in HIV-2-infected patients. AIDS 22: 665-666.

Davidson A, Leeper TC, Athanassiou Z, Patora-Komisarska K, Karn J, Robinson JA, Varani G. 2009. Simultaneous recognition of HIV-1 TAR RNA bulge and loop sequences by cyclic peptide mimics of Tat protein. Proc Natl Acad Sci 106: 11931-11936.

Davies WL, Grunert RR, Haff RF, Mcgahen JW, Neumayer EM, Paulshock M, Watts JC, Wood TR, Hermann EC, Hoffmann CE. 1964. Antiviral activity of 1-adamantanamine (amantadine). Science 144: 862-863.

Deeks SG. 2001. International perspectives on antiretroviral resistance. Nonnucleoside reverse transcriptase inhibitor resistance. J Acquir Immune Defic Syndr 26: S25-S33.

Demeter LM, Shafer RW, Meehan PM, Holden-Wiltse J, Fischl MA, Freimuth WW, Para MF, Reichman RC. 2000. Delavirdine susceptibilities and associated reverse transcriptase mutations in human immunodeficiency virus type 1 isolates from patients in a phase I/II trial of delavirdine monotherapy (ACTG 260). Antimicrob Agents Chemother 44: 794-797.

Deng H, Liu R, Ellmeier W, Choe S, Unutmaz D, Burkhart M, Di Marzio P, Marmon S, Sutton RE, Hill CM, et al.
1996. Identification of a major co-receptor for primary isolates of HIV-1. Nature (London) 381: 661-666.

Derdeyn CA, Decker JM, Sfakianos JN, Wu X, O'Brien WA, Ratner L, Kappes JC, Shaw GM, Hunter E. 2000. Sensitivity of human immunodeficiency virus type 1 to the fusion inhibitor T-20 is modulated by coreceptor specificity defined by the V3 loop of gp120. J Virol 74: 8358-8367.

Deval J, White KL, Miller MD, Parkin NT, Courcambeck J, Halfon P, Selmi B, Boretto J, Canard B. 2004. Mechanistic basis for reduced viral and enzymatic fitness of HIV-1 reverse transcriptase containing both K65R and M184V mutations. J Biol Chem 279: 509-516.

Doranz BJ, Rucker J, Yi Y, Smyth RJ, Samson M, Peiper SC, Parmentier M, Collman RG, Doms RW. 1996. A dualtropic primary HIV-1 isolate that uses fusin and the betachemokine receptors CKR-5, CKR-3, and CKR-2b as fusion cofactors. Cell 85: 1149-1158.

Dorr P, Westby M, Dobbs S, Griffin P, Irvine B, Macartney M, Mori J, Rickett G, Smith-Burchnell C, Napier C, et al. 2005. Maraviroc (UK-427,857), a potent, orally bioavailable, and selective small-molecule inhibitor of chemokine receptor CCR5 with broad-spectrum antihuman immunodeficiency virus type 1 activity. Antimicrob Agents Chemother 49: 4721-4732.

Doyon L, Croteau G, Thibeault D, Poulin F, Pilote L, Lamarre D. 1996. Second locus involved in human immunodeficiency virus type 1 resistance to protease inhibitors. J Virol 70: 3763-3769.

Doyon L, Payant C, Brakier-Gingras L, Lamarre D. 1998. Novel Gag-Pol frameshift site in human immunodeficiency virus type 1 variants resistant to protease inhibitors. J Virol 72: 6146-6150.

Dragic T, Trkola A, Thompson DA, Cormier EG, Kajumo FA, Maxwell E, Lin SW, Ying W, Smith SO, Sakmar TP, et al. 2000. A binding pocket for a small molecule inhibitor of HIV-1 entry within the transmembrane helices of CCR5. Proc Natl Acad Sci 97: 5639-5644.

Dykes C, Fox K, Lloyd A, Chiulli M, Morse E, Demeter LM. 2001. Impact of clinical reverse transcriptase sequences on the replication capacity of HIV-1 drug-resistant mutants. Virology 285: 193-203.

Espeseth AS, Felock P, Wolfe A, Witmer M, Grobler J, Anthony N, Egbertson M, Melamed JY, Young S, Hamill T, et al. 2000. HIV-1 integrase inhibitors that compete with the target DNA substrate define a unique strand transfer conformation for integrase. Proc Natl Acad Sci 97: 11244-11249.

Feng Y, Broder CC, Kennedy PE, Berger EA. 1996. HIV-1 entry cofactor: Functional cDNA cloning of a seventransmembrane, G protein-coupled receptor. Science 272: $872-877$.

Finzi D, Hermankova M, Pierson T, Carruth LM, Buck C, Chaisson RE, Quinn TC, Chadwick K, Margolick J, Brookmeyer R, et al. 1997. Identification of a reservoir for HIV-1 in patients on highly active antiretroviral therapy. Science 278: 1295-1300.

Finzi D, Blankson J, Siliciano JD, Margolick JB, Chadwick K, Pierson T, Smith K, Lisziewicz J, Lori F, Flexner C, et al. 1999. Latent infection of $\mathrm{CD} 4^{+} \mathrm{T}$ cells provides a mechanism for lifelong persistence of HIV-1, even in patient on effective combination therapy. Nat Med 5: 512-517. 
Fransen S, Gupta S, Danovich R, Hazuda D, Miller M, Witmer M, Petropoulos CJ, Huang W.2009. Loss of Raltegravir susceptibility of HIV-1 is conferred by multiple non-overlapping genetic pathways. J Virol 83: 1144011446.

Frost SD, McLean AR. 1994. Quasispecies dynamics and the emergence of drug resistance during zidovudine therapy of HIV infection. AIDS 8: 323-332.

Fujioka T, Kashiwada Y, Kilkuskie RE, Cosentino LM, Ballas LM, Jiang JB, Janzen WP, Chen IS, Lee KH. 1994 Anti-AIDS agents, 11. Betulinic acid and platanic acid as anti-HIV principles from Syzigium claviflorum, and the anti-HIV activity of structurally related triterpenoids. J Nat Prod 57: 243-247.

Furman PA, Fyfe JA, St Clair MH, Weinhold K, Rideout JL, Freeman GA, Lehrman SN, Bolognesi DP, Broder S, Mit suya H. 1986. Phosphorylation of $3^{\prime}$-azido- $3^{\prime}$-deoxythymidine and selective interaction of the $5^{\prime}$-triphosphate with human immunodeficiency virus reverse transcriptase. Proc Natl Acad Sci 83: 8333-8337.

Gao Y, Paxinos E, Galovich J, Troyer R, Baird H, Abreha M, Kityo C, Mugyenyi P, Petropoulos C, Arts EJ. 2004. Characterization of a subtype D human immunodeficiency virus type 1 isolate that was obtained from an untreated individual and that is highly resistant to nonnucleoside reverse transcriptase inhibitors. J Virol 78: 5390-5401.

Garcia-Lerma JG, MacInnes H, Bennett D, Reid P, Nidtha S, Weinstock H, Kaplan JE, Heneine W. 2003. A novel genetic pathway of human immunodeficiency virus type 1 resistance to stavudine mediated by the K65R mutation. J Virol 77: 5685-5693.

Garrido C, Geretti A, Zahonero N, Booth C, Strang A, Soriano V, De Mendoza C, et al. 2010. Integrase variability and susceptibility to HIV integrase inhibitors: Impact of subtypes, antiretroviral experience and duration of HIV infection. J Antimicrob Chemother 65: 320-326.

Goethals O, Clayton R, Van Ginderen M, Vereycken I, Wagemans E, Geluykens P, Dockx K, Strijbos R, Smits V, Vos A, et al. 2008. Resistance mutations in HIV type 1 integrase selected with elvitegravir confer reduced susceptibility to a wide range of integrase inhibitors. J Virol 82: 10366-10374.

Grobler JA, Stillmock K, Hu B, Witmer M, Felock P, Espeseth AS, Wolfe A, Egbertson M, Bourgeois M, Melamed J, et al. 2002. Diketo acid inhibitor mechanism and HIV-1 integrase: Implications for metal binding in the active site of phosphotransferase enzymes. Proc Natl Acad Sci 99: 6661-6666.

Hamy F, Felder ER, Heizmann G, Lazdins J, Aboul-ela F, Varani G, Karn J, Klimkait T. 1997. An inhibitor of the Tat/TAR RNA interaction that effectively suppresses HIV-1 replication. Proc Natl Acad Sci 94: 3548-3553.

Hare S, Vos AM, Clayton RF, Thuring JW, Cummings MD, Cherepanov P. 2010. Molecular mechanisms of retroviral integrase inhibition and the evolution of viral resistance. Proc Natl Acad Sci 107: 20057-20062.

Harrigan PR, Kinghorn I, Bloor S, Kemp SD, Najera I, Kohli A, Larder BA. 1996. Significance of amino acid variation at human immunodeficiency virus type 1 reverse transcriptase residue 210 for zidovudine susceptibility. J Virol 70: $5930-5934$.
Hart GJ, Orr DC, Penn CR, Figueiredo HT, Gray NM, Boehme RE, Cameron JM. 1992. Effects of $(-)-2^{\prime}$ deoxy-3'-thiacytidine (3TC) $5^{\prime}$-triphosphate on human immunodeficiency virus reverse transcriptase and mammalian DNA polymerases alpha, beta, and gamma. Antimicrob Agents Chemother 36: 1688-1694.

Hay AJ, Wolstenholme AJ, Skehel JJ, Smith MH. 1985. The molecular basis of the specific anti-influenza action of amantadine. EMBO J 4: 3021-3024.

Hazuda DJ, Anthony NJ, Gomez RP, Jolly SM, Wai JS, Zhuang L, Fisher TE, Embrey M, Guare JP Jr, Egbertson MS, et al. 2004a. A naphthyridine carboxamide provides evidence for discordant resistance between mechanistically identical inhibitors of HIV-1 integrase. Proc Natl Acad Sci 101: 11233-11238.

Hazuda DJ, Young SD, Guare JP, Anthony NJ, Gomez RP, Wai JS, Vacca JP, Handt L, Motzel SL, Klein HJ, et al. 2004b. Integrase inhibitors and cellular immunity suppress retroviral replication in rhesus macaques. Science 305: $528-532$.

Hendrix CW, Collier AC, Lederman MM, Schols D, Pollard RB, Brown S, Jackson JB, Coombs RW, Glesby MJ, Flexner CW, et al. 2004. Safety, pharmacokinetics, and antiviral activity of AMD3100, a selective CXCR4 receptor inhibitor, in HIV-1 infection. J Acquir Immune Defic Syndr 37: 1253-1262.

Ho DD, Neumann AU, Perelson AS, Chen W, Leonard JM, Markowitz M. 1995. Rapid turnover of plasma virions and CD4 lymphocytes in HIV-1 infection. Nature (London) 373: 123-126.

Hsiou Y, Ding J, Das K, Clark AD Jr, Hughes SH, Arnold E. 1996. Structure of unliganded HIV-1 reverse transcriptase at 2.7 A resolution: Implications of conformational changes for polymerization and inhibition mechanisms. Structure 4: 853-860.

Hsu MC, Schutt AD, Holly M, Slice LW, Sherman MI, Richman DD, Potash MJ, Volsky DJ. 1991. Inhibition of HIV replication in acute and chronic infections in vitro by a Tat antagonist. Science 254: 1799-1802.

Hsu A, Granneman GR, Cao G, Carothers L, El-Shourbagy T, Baroldi P, Erdman K, Brown F, Sun E, Leonard JM 1998. Pharmacokinetic interactions between two human immunodeficiency virus protease inhibitors, ritonavir and saquinavir. Clin Pharmacol Ther 63: 453-464.

* Hu W-S, Hughes SH. 2011. HIV-1 reverse transcription. Cold Spring Harb Perspect Med doi: 10/1101/cshper spect.a006882.

Huang H, Chopra R, Verdine GL, Harrison SC. 1998. Structure of a covalently trapped catalytic complex of HIV-1 reverse transcriptase: Implications for drug resistance. Science 282: 1669-1675.

Hwang S, Tamilarasu N, Kibler K, Cao H, Ali A, Ping YH, Jeang KT, Rana TM. 2003. Discovery of a small molecule Tat-trans-activation-responsive RNA antagonist that potently inhibits human immunodeficiency virus-1 replication. J Biol Chem 278: 39092-39103.

Imamichi T, Murphy MA, Imamichi H, Lane HC. 2001. Amino acid deletion at codon 67 and Thr-to-Gly change at codon 69 of human immunodeficiency virus type 1 reverse transcriptase confer novel drug resistance profiles. J Virol 75: 3988-3992. 
* Karn J, Stoltzfus CM. 2011. Transcriptional and posttranscriptional regulation of HIV-1 gene expression. Cold Spring Harb Perspect Med doi: 10.1101/cshperspect. a006916.

Kellam P, Boucher CA, Larder BA. 1992. Fifth mutation in human immunodeficiency virus type 1 reverse transcriptase contributes to the development of high-level resistance to zidovudine. Proc Natl Acad Sci 89: 1934-1938.

Kempf DJ, Marsh KC, Kumar G, Rodrigues AD, Denissen JF, McDonald E, Kukulka MJ, Hsu A, Granneman GR, Baroldi PA, et al. 1997. Pharmacokinetic enhancement of inhibitors of the human immunodeficiency virus protease by coadministration with ritonavir. Antimicrob Agents Chemother 41: 654-660.

Kilby JM, Hopkins S, Venetta TM, DiMassimo B, Cloud GA, Lee JY, Alldredge L, Hunter E, Lambert D, Bolognesi D, et al. 1998. Potent suppression of HIV-1 replication in humans by T-20, a peptide inhibitor of gp41-mediated virus entry. Nat Med 4: 1302-1307.

Klatzmann D, Champagne E, Chamaret S, Gruest J, Guetard D, Hercend T, Gluckman JC, Montagnier L. 1984. T-lymphocyte T4 molecule behaves as the receptor for human retrovirus LAV. Nature 312: 767-768.

Kohlstaedt LA, Wang J, Friedman JM, Rice PA, Steitz TA. 1992. Crystal structure at 3.5 A resolution of HIV-1 reverse transcriptase complexed with an inhibitor. Science 256: 1783-1790.

Komanduri KV, Viswanathan MN, Wieder ED, Schmidt DK, Bredt BM, Jacobson MA, McCune JM. 1998. Restoration of cytomegalovirus-specific $\mathrm{CD} 4^{+}$T-lymphocyte responses after ganciclovir and highly active antiretroviral therapy in individuals infected with HIV-1. Nat Med 4: 953-956.

Kondru R, Zhang J, Ji C, Mirzadegan T, Rotstein D, Sankuratri S, Dioszegi M. 2008. Molecular interactions of CCR5 with major classes of small-molecule anti-HIV CCR5 antagonists. Mol Pharmacol 73: 789-800.

Kozal MJ, Shah N, Shen N, Yang R, Fucini R, Merigan TC, Richman DD, Morris D, Hubbel E, Chee M, et al. 1996. Extensive polymorphisms observed in HIV-1 clade B protease gene using high-density oligonucleotide arrays. Nature Med 2: 753-759.

Kuhmann SE, Pugach P, Kunstman KJ, Taylor J, Stanfield RL, Snyder A, Strizki JM, Riley J, Baroudy BM, Wilson IA, et al. 2004. Genetic and phenotypic analyses of human immunodeficiency virus type 1 escape from a smallmolecule CCR5 inhibitor. J Virol 78: 2790-2807.

Kuritzkes DR, Jacobson J, Powderly WG, Godofsky E, DeJesus E, Haas F, Reimann KA, Larson JL, Yarbough PO, Curt V Jr, et al. 2004. Antiretroviral activity of the anti-CD4 monoclonal antibody TNX-355 in patients infected with HIV type 1. J Infect Dis 189: 286-291.

Labrosse B, Labernardiere JL, Dam E, Trouplin V, Skrabal K, Clavel F, Mammano F. 2003. Baseline susceptibility of primary human immunodeficiency virus type 1 to entry inhibitors. J Virol 77: 1610-1613.

Lalezari JP, Henry K, O’Hearn M, Montaner JS, Piliero PJ, Trottier B, Walmsley S, Cohen C, Kuritzkes DR, Eron JJ Jr, et al. 2003. Enfuvirtide, an HIV-1 fusion inhibitor, for drug-resistant HIV infection in North and South America. N Engl J Med 348: 2175-2185.
Lalonde M, Lobritz M, Ratcliff A, Chaminian M, Athanassiou Z, Tyagi M, Karn J, Robinson JA, Varani G, Arts EJ. 2011. Inhibition of both HIV-1 reverse transcription and gene expression by a cyclic peptide that binds the Tat-transactivating response element (TAR) RNA. PLoS Pathog 7: e1002038.

Lansdon EB, Brendza KM, Hung M, Wang R, Mukund S, Jin D, Birkus G, Kutty N, Liu X. 2010. Crystal structures of HIV-1 reverse transcriptase with etravirine (TMC125) and rilpivirine (TMC278): Implications for drug design. J Med Chem 53: 4295-4299.

Larder BA, Kemp SD. 1989. Multiple mutations in HIV-1 reverse transcriptase confer high-level resistance to zidovudine (AZT). Science 246: 1155-1158.

Larder BA, Kemp SD, Harrigan PR. 1995. Potential mechanism for sustained antiretroviral efficacy of AZT-3TC combination therapy. Science 269: 696-699.

Lederman MM, Connick E, Landay A, Kuritzkes DR, Spritzler J, St Clair M, Kotzin BL, Fox L, Chiozzi MH, Leonard JM, et al. 1998. Immunologic responses associated with 12 weeks of combination antiretroviral therapy consisting of zidovudine, lamivudine, and ritonavir: Results of AIDS Clinical Trials Group Protocol 315. J Infect Dis 178: 70-79.

Li F, Goila-Gaur R, Salzwedel K, Kilgore NR, Reddick M, Matallana C, Castillo A, Zoumplis D, Martin DE, Orenstein JM, et al. 2003. PA-457: A potent HIV inhibitor that disrupts core condensation by targeting a late step in Gag processing. Proc Natl Acad Sci 100: 13555-13560.

Lin PF, Blair W, Wang T, Spicer T, Guo Q, Zhou N, Gong YF, Wang HG, Rose R, Yamanaka G, et al. 2003. A small molecule HIV-1 inhibitor that targets the HIV-1 envelope and inhibits CD4 receptor binding. Proc Natl Acad Sci 100: 11013-11018.

Lobritz MA, Marozsan AJ, Troyer RM, Arts EJ. 2007. Natural variation in the $\mathrm{V} 3$ crown of human immunodeficiency virus type 1 affects replicative fitness and entry inhibitor sensitivity. J Virol 81: 8258-8269.

Maignan S, Guilloteau JP, Zhou-Liu Q, Clement-Mella C, Mikol V. 1998. Crystal structures of the catalytic domain of HIV-1 integrase free and complexed with its metal cofactor: High level of similarity of the active site with other viral integrases. J Mol Biol. 282: 359-68.

Malashkevich VN, Chan DC, Chutkowski CT, Kim PS. 1998. Crystal structure of the simian immunodeficiency virus (SIV) gp41 core: Conserved helical interactions underlie the broad inhibitory activity of gp41 peptides. Proc Natl Acad Sci 95: 9134-9139.

* Malim MH, Bieniasz PD. 2011. HIV restriction factors and mechanisms of evasion. Cold Spring Harb Perspect Med doi: $10.1101 /$ cshperspect.a006940.

Mammano F, Petit C, Clavel F. 1998. Resistance-associated loss of viral fitness in human immunodeficiency virus type 1: Phenotypic analysis of protease and gag coevolution in protease inhibitor-treated patients. J Virol 72: $7632-7637$.

Mansky LM, Temin HM. 1995. Lower in vivo mutation rate of human immunodeficiency virus type 1 than that predicted from the fidelity of purified reverse transcriptase. $J$ Virol 69: 5087-5094.

Marcelin AG, Delaugerre C, Wirden M, Viegas P, Simon A, Katlama C, Calvez V. 2004. Thymidine analogue reverse 
transcriptase inhibitors resistance mutations profiles and association to other nucleoside reverse transcriptase inhibitors resistance mutations observed in the context of virological failure. J Med Virol 72: 162-165.

Marinello J, Marchand C, Mott B, Bain A, Thomas CJ, Pommier Y. 2008. Comparison of raltegravir and elvitegravir on HIV-1 integrase catalytic reactions and on a series of drug-resistant integrase mutants. Biochemistry 47: 9345-54.

Margot NA, Isaacson E, McGowan I, Cheng AK, Schooley RT, Miller MD. 2002. Genotypic and phenotypic analyses of HIV-1 in antiretroviral-experienced patients treated with tenofovir DF. AIDS 16: 1227-1235.

Marozsan AJ, Moore DM, Lobritz MA, Fraundorf E, Abraha A, Reeves JD, Arts EJ. 2005. Differences in the fitness of two diverse wild-type human immunodeficiency virus type 1 isolates are related to the efficiency of cell binding and entry. J Virol 79: 7121-7134.

McColl DJ, Chen X. 2010. Strand transfer inhibitors of HIV-1 integrase: Bringing IN a new era of antiretroviral therapy. Antiviral Res 85: 101-118.

Meyer PR, Matsuura SE, Mian AM, So AG, Scott WA. 1999. A mechanism of AZT resistance: An increase in nucleotide-dependent primer unblocking by mutant HIV-1 reverse transcriptase. Mol Cell Biol 4: 35-43.

Meyer PR, Matsuura SE, Tolun AA, Pfeifer I, So AG, Mellors JW, Scott WA. 2002. Effects of specific zidovudine resistance mutations and substrate structure on nucleotide-dependent primer unblocking by human immunodeficiency virus type 1 reverse transcriptase. Antimicrob Agents Chemother 46: 1540-1545.

Miller V. 2001. International perspectives on antiretroviral resistance. Resistance to protease inhibitors. J Acquir Immune Defic Syndr 26 (Suppl 1): S34-S50.

Mitsuya H, Broder S. 1986. Inhibition of the in vitro infectivity and cytopathic effect of human T-lymphotrophic virus type III/lymphadenopathy-associated virus (HTLV-III/LAV) by $2^{\prime}, 3^{\prime}$-dideoxynucleosides. Proc Natl Acad Sci 83: 1911-1915.

Mitsuya H, Weinhold KJ, Furman PA, St Clair MH, Lehrman SN, Gallo RC, Bolognesi D, Barry DW, Broder S. 1985. 3'-Azido-3'-deoxythymidine (BW A509U): An antiviral agent that inhibits the infectivity and cytopathic effect of human T-lymphotropic virus type III/lymphadenopathy-associated virus in vitro. Proc Natl Acad Sci 82: 7096-7100.

Molla A, Korneyeva M, Gao Q, Vasavanonda S, Schipper PJ, Mo HM, Markowitz M, Chernyavskiy T, Niu P, Lyons N, et al. 1996a. Ordered accumulation of mutations in HIV protease confers resistance to ritonavir. Nat Med 2: $760-766$.

Molla A, Korneyeva M, Gao Q, Vasavanonda S, Schipper PJ, Mo HM, Markowitz M, Chernyavskiy T, Niu P, Lyons N, et al. 1996b. Ordered accumulation of mutations in HIV protease confers resistance to ritonavir. Nat Med 2: $760-766$.

Naeger LK, Margot NA, Miller MD. 2002. ATP-dependent removal of nucleoside reverse transcriptase inhibitors by human immunodeficiency virus type 1 reverse transcriptase. Antimicrob Agents Chemother 46: 2179-2184.

Nagashima KA, Thompson DA, Rosenfield SI, Maddon PJ, Dragic T, Olson WC. 2001. Human immunodeficiency virus type 1 entry inhibitors PRO 542 and T-20 are potently synergistic in blocking virus-cell and cell-cell fusion. J Infect Dis 183: 1121-1125.

Nijhuis M, Deeks S, Boucher C. 2001. Implications of antiretroviral resistance on viral fitness. Curr Opin Infect Dis 14: $23-28$.

Nowak MA, Bonhoeffer S, Shaw GM, May RM. 1997. Antiviral drug treatment: Dynamics of resistance in free virus and infected cell populations. J Theor Biol 184: 203-217.

O’Neil PK, Sun G, Yu H, Ron Y, Dougherty JP, Preston BD. 2002. Mutational analysis of HIV-1 long terminal repeats to explore the relative contribution of reverse transcriptase and RNA polymerase II to viral mutagenesis. J Biol Chem 277: 38053-38061.

Parikh UM, Bacheler L, Koontz D, Mellors JW. 2006. The K65R mutation in human immunodeficiency virus type 1 reverse transcriptase exhibits bidirectional phenotypic antagonism with thymidine analog mutations. $J$ Virol 80: 4971-4977.

Park J, Morrow CD. 1993. Mutations in the protease gene of human immunodeficiency virus type 1 affect release and stability of virus particles. Virology 194: 843-850.

Perelson AS, Neumann AU, Markowitz M, Leonard JM, Ho DD. 1996. HIV-1 dynamics in vivo: Virion clearance rate, infected cell life-span, and viral generation time. 15821586.

Quan Y, Gu Z, Li X, Li Z, Morrow CD, Wainberg MA. 1996. Endogenous reverse transcription assays reveal high-level resistance to the triphosphate of $(-) 2^{\prime}$-dideoxy- $3^{\prime}$-thiacytidine by mutated M184V human immunodeficiency virus type 1. J Virol 70: 5642-5645.

Quercia R, Dam E, Perez-Bercoff D, Clavel F. 2009. Selective-advantage profile of human immunodeficiency virus type 1 integrase mutants explains in vivo evolution of raltegravir resistance genotypes. Virol J 83: 1024510249.

Quinones-Mateu ME, Arts EJ. 2002. Fitness of drug resistant HIV-1: Methodology and clinical implications. Drug Resist Updat 5: 224-233.

Quinones-Mateu ME, Arts EJ. 2006. Virus fitness: Concept, quantification, and application to HIV population dynamics. Curr Top Microbiol Immunol 299: 83-140.

Quinones-Mateu ME, Moore-Dudley DM, Jegede O, Weber J, Arts J. 2008. Viral drug resistance and fitness. Adv Pharmacol 56: 257-296.

Ray PE, Soler-Garcia AA, Xu L, Soderland C, Blumenthal R, Puri A. 2005. Fusion of HIV-1 envelope-expressing cells to human glomerular endothelial cells through an CXCR4-mediated mechanism. Pediatr Nephrol 20: 1401-1409.

Reeves JD, Gallo SA, Ahmad N, Miamidian JL, Harvey PE, Sharron M, Pohlmann S, Sfakianos JN, Derdeyn CA, Blumenthal R, et al. 2002. Sensitivity of HIV-1 to entry inhibitors correlates with envelope/coreceptor affinity, receptor density, and fusion kinetics. Proc Natl Acad Sci 99: $16249-16254$.

Reeves JD, Miamidian JL, Biscone MJ, Lee FH, Ahmad N, Pierson TC, Doms RW. 2004. Impact of mutations in the coreceptor binding site on human immunodeficiency virus type 1 fusion, infection, and entry inhibitor sensitivity. J Virol 78: 5476-5485. 
E.J. Arts and D.J. Hazuda

Reeves JD, Lee FH, Miamidian JL, Jabara CB, Juntilla MM Doms RW. 2005. Enfuvirtide resistance mutations: Impact on human immunodeficiency virus envelope function, entry inhibitor sensitivity, and virus neutralization. J Virol 79: 4991-4999.

Reimann KA, Lin W, Bixler S, Browning B, Ehrenfels BN, Lucci J, Miatkowski K, Olson D, Parish TH, Rosa MD, et al. 1997. A humanized form of a CD4-specific monoclonal antibody exhibits decreased antigenicity and prolonged plasma half-life in rhesus monkeys while retaining its unique biological and antiviral properties. AIDS Res Hum Retroviruses 13: 933-943.

Richman DD. 2001. HIV chemotherapy. Nature 410: $995-$ 1001.

Rimsky LT, Shugars DC, Matthews TJ. 1998. Determinants of human immunodeficiency virus type 1 resistance to gp41-derived inhibitory peptides. J Virol 72: 986-993.

Rodgers DW, Gamblin SJ, Harris BA, Ray S, Culp JS, Hellmig B, Woolf DJ, Debouck C, Harrison SC. 1995. The structure of unliganded reverse transcriptase from the human immunodeficiency virus type 1. Proc Natl Acad Sci 92: 1222-1226.

Sato M, Motomura T, Aramaki H, Matsuda T, Yamashita M, Ito Y, Kawakami H, Matsuzaki Y, Watanabe W, Yamataka K, et al. 2006. Novel HIV-1 integrase inhibitors derived from quinolone antibiotics. J Med Chem 49: 1506-1508.

Schinazi RF, Lloyd RM Jr, Nguyen MH, Cannon DL, McMillan A, Ilksoy N, Chu CK, Liotta DC, Bazmi HZ, Mellors JW. 1993. Characterization of human immunodeficiency viruses resistant to oxathiolane-cytosine nucleosides. Antimicrob Agents Chemother 37: 875-881.

Shafer RW, Dupnik K, Winters MA, Eshleman SH. 2000. A guide to HIV-1 reverse transcriptase and protease sequencing for drug resistance studies. In HIV sequence compendium 2000 (ed. Kuiken CL, et al.). Los Alamos National Laboratory, Los Alamos, NM.

Shehu-Xhilaga M, Tachedjian G, Crowe SM, Kedzierska K. 2005. Antiretroviral compounds: Mechanisms underlying failure of HAART to eradicate HIV-1. Curr Med Chem 12: 1705-1719.

Shimura K, Kodama E, Sakagami Y, Matsuzaki Y, Watanabe W, Yamataka K, Watanabe Y, Ohata Y, Doi S, Sato M, et al. 2008. Broad antiretroviral activity and resistance profile of the novel human immunodeficiency virus integrase inhibitor elvitegravir (JTK-303/GS-9137). J Virol 82: 764-774.

Singh I, Gorzynski J, Drobysheva D, Bassit L, Schinazi R. 2010. Raltegravir is a potent inhibitor of XMRV, a virus implicated in prostate cancer and chronic fatigue syndrome. PLoS One. 5: e9948. doi: 10.1371/ journal.pone.0009948.

Sluis-Cremer N, Temiz NA, Bahar I. 2004. Conformational changes in HIV-1 reverse transcriptase induced by nonnucleoside reverse transcriptase inhibitor binding. Curr HIV Res 2: 323-332.

Smith PF, Ogundele A, Forrest A, Wilton J, Salzwedel K, Doto J, Allaway GP, Martin DE. 2007. Phase I and II study of the safety, virologic effect, and pharmacokinetics/ pharmacodynamics of single-dose 3-o- $\left(3^{\prime}, 3^{\prime}\right.$-dimethylsuccinyl)betulinic acid (bevirimat) against human immunodeficiency virus infection. Antimicrob Agents Chemother 51: 3574-3581.
Spence RA, Kati WM, Anderson KS, Johnson KA. 1995. Mechanism of inhibition of HIV-1 reverse transcriptase by nonnucleoside inhibitors. Science 267: 988-993.

Spira S, Wainberg MA, Loemba H, Turner D, Brenner BG. 2003. Impact of clade diversity on HIV-1 virulence, antiretroviral drug sensitivity and drug resistance. J Antimicrob Chemother 51: 229-240.

Staszewski S, Miller V, Rehmet S, Stark T, De CJ, De BM, Peeters M, Andries K, Moeremans M, De RM, et al. 1996. Virological and immunological analysis of a triple combination pilot study with loviride, lamivudine and zidovudine in HIV-1-infected patients. AIDS 10: F1-F7.

St Clair MH, Richards CA, Spector T, Weinhold KJ, Miller WH, Langlois AJ, Furman PA. 1987.3'-Azido-3'-deoxythymidine triphosphate as an inhibitor and substrate of purified human immunodeficiency virus reverse transcriptase. Antimicrob Agents Chemother 31: 1972-1977.

Stengel RF. 2008. Mutation and control of the human immunodeficiency virus. Math Biosci 213: 93-102.

* Sundquist WI, Kräusslich H-G. 2011. Assembly, budding, and maturation. Cold Spring Harb Perspect Med doi: 10.1101/cshperspect.1006924.

Tantillo C, Ding J, Jacobo-Molina A, Nanni RG, Boyer PL, Hughes SH, Pauwels R, Andries K, Janssen PA, Arnold EA. et al. 1994. Locations of anti-AIDS drug binding sites and resistance mutations in the three-dimensional structure of HIV-1 reverse transcriptase. Implications for mechanisms of drug inhibition and resistance. $J \mathrm{Mol}$ Biol 243: 369-387.

Tebit DM, Lobritz M, Lalonde M, Immonen T, Singh K, Sarafianos S, Herchenroder O, Krausslich HG, Arts EJ. 2010. Divergent evolution in reverse transcriptase (RT) of HIV-1 group $\mathrm{O}$ and $\mathrm{M}$ lineages: Impact on structure, fitness, and sensitivity to nonnucleoside RT inhibitors. J Virol 84: 9817-9830.

Torre VS, Marozsan AJ, Albright JL, Collins KR, Hartley O, Offord RE, Quinones-Mateu ME, Arts EJ. 2000. Variable sensitivity of CCR5-tropic human immunodeficiency virus type 1 isolates to inhibition by RANTES analogs. $J$ Virol 74: 4868-4876.

Tremblay CL, Kollmann C, Giguel F, Chou TC, Hirsch MS. 2000. Strong in vitro synergy between the fusion inhibitor T-20 and the CXCR4 blocker AMD-3100. J Acquir Immune Defic Syndr 25: 99-102.

Trkola A, Kuhmann SE, Strizki JM, Maxwell E, Ketas T, Morgan T, Pugach P, Xu S, Wojcik L, Tagat J, et al. 2002. HIV-1 escape from a small molecule, CCR5-specific entry inhibitor does not involve CXCR4 use. Proc Natl Acad Sci 99: 395-400.

Tsamis F, Gavrilov S, Kajumo F, Seibert C, Kuhmann S, Ketas T, Trkola A, Palani A, Clader JW, Tagat JR, et al. 2003. Analysis of the mechanism by which the small-molecule CCR5 antagonists SCH-351125 and SCH-350581 inhibit human immunodeficiency virus type 1 entry. J Virol 77: 5201-5208.

Tsibris AM, Sagar M, Gulick RM, Su Z, Hughes M, Greaves W, Subramanian M, Flexner C, Giguel F, Leopold KE, et al. 2008. In vivo emergence of vicriviroc resistance in a human immunodeficiency virus type 1 subtype Cinfected subject. J Virol 82: 8210-8214.

Van Baelen K, Van Eygen V, Rondelez E, Stuyver LJ. 2008. Clade-specific HIV-1 integrase polymorphisms do not 
reduce raltegravir elvitegravir phenotypic susceptibility. AIDS 22: 1877-80.

Veazey RS, Klasse PJ, Ketas TJ, Reeves JD, Piatak M Jr, Kunstman K, Kuhmann SE, Marx PA, Lifson JD, Dufour J, et al. 2003. Use of a small molecule CCR5 inhibitor in macaques to treat simian immunodeficiency virus infection or prevent simian-human immunodeficiency virus infection. J Exp Med 198: 1551-1562.

Veazey RS, Klasse PJ, Schader SM, Hu Q, Ketas TJ, Lu M, Marx PA, Dufour J, Colonno RJ, Shattock RJ, et al. 2005. Protection of macaques from vaginal SHIV challenge by vaginally delivered inhibitors of virus-cell fusion. Nature (London) 438: 99-102.

Wainberg MA, Miller MD, Quan Y, Salomon H, Mulato AS, Lamy PD, Margot NA, Anton KE, Cherrington JM. 1999. In vitro selection and characterization of HIV-1 with reduced susceptibility to PMPA. Antiviral Therapy 4: 87-94.

Wei X, Ghosh SK, Taylor ME, Johnson VA, Emini EA, Deutsch P, Lifson JD, Bonhoeffer S, Nowak MA, Hahn BH. 1995. Viral dynamics in human immunodeficiency virus type 1 infection. Nature (London) 373: 117-122.

Wei X, Decker JM, Liu H, Zhang Z, Arani RB, Kilby JM, Saag MS, Wu X, Shaw GM, Kappes JC. 2002. Emergence of resistant human immunodeficiency virus type 1 in patients receiving fusion inhibitor (T-20) monotherapy. Antimicrob Agents Chemother 46: 1896-1905.

Westby M, Lewis M, Whitcomb J, Youle M, Pozniak AL, James IT, Jenkins TM, Perros M, van der Ryst E. 2006. Emergence of CXCR4-using human immunodeficiency virus type 1 (HIV-1) variants in a minority of HIV-1infected patients following treatment with the CCR5 antagonist maraviroc is from a pretreatment CXCR4using virus reservoir. J Virol 80: 4909-4920.

Westby M, Smith-Burchnell C, Mori J, Lewis M, Mosley M Stockdale M, Dorr P, Ciaramella G, Perros M. 2007. Reduced maximal inhibition in phenotypic susceptibility assays indicates that viral strains resistant to the CCR5 antagonist maraviroc utilize inhibitor-bound receptor for entry. J Virol 81: 2359-2371.

White KL, Chen JM, Feng JY, Margot NA, Ly JK, Ray AS, Macarthur HL, McDermott MJ, Swaminathan S, Miller MD. 2006. The K65R reverse transcriptase mutation in HIV-1 reverses the excision phenotype of zidovudine resistance mutations. Antiviral Therapy 11: 155-163.
Wild C, Greenwell T, Matthews T. 1993. A synthetic peptide from HIV-1 gp41 is a potent inhibitor of virus-mediated cell-cell fusion. AIDS Res Hum Retroviruses 9: 10511053.

Wild CT, Shugars DC, Greenwell TK, McDanal CB, Matthews TJ. 1994. Peptides corresponding to a predictive alpha-helical domain of human immunodeficiency virus type $1 \mathrm{gp} 41$ are potent inhibitors of virus infection. Proc Natl Acad Sci 91: 9770-9774.

* Wilen CB, Tilton JC, Doms RW. 2011. HIV: Cell binding and entry. Cold Spring Harb Perspect Med doi: 10.1101/ cshperspect.a006866.

Wingfield WL, Pollack D, Grunert RR. 1969. Therapeutic efficacy of amantadine $\mathrm{HCl}$ and rimantadine $\mathrm{HCl}$ in naturally occurring influenza $\mathrm{A} 2$ respiratory illness in man. N Engl J Med 281: 579-584.

Witvrouw M, Pannecouque C, Van Laethem K, Desmyter J, De Clercq E, Vandamme AM. 1999. Activity of nonnucleoside reverse transcriptase inhibitors against HIV-2 and SIV. AIDS 13: 1477-1483.

Wu B, Chien EY, Mol CD, Fenalti G, Liu W, Katritch V, Abagyan R, Brooun A, Wells P, Bi FC, et al. 2010. Structures of the CXCR4 chemokine GPCR with smallmolecule and cyclic peptide antagonists. Science 330: 1066-1071.

Yahi N, Fantini J, Henry M, Tourres C, Tamalet C. 2005. Structural analysis of reverse transcriptase mutations at codon 215 explains the predominance of T215Y over T215F in HIV-1 variants selected under antiretroviral therapy. J Biomed Sci 12: 701-710.

Young FE. 1988. The role of the FDA in the effort against AIDS. Public Health Rep 103: 242-245.

Zennou V, Mammano F, Paulous S, Mathez D, Clavel F. 1998. Loss of viral fitness associated with multiple Gag and Gag-Pol processing defects in human immunodeficiency virus type 1 variants selected for resistance to protease inhibitors in vivo. J Virol 72: 3300-3306.

Zhang YM, Imamichi H, Imamichi T, Lane HC, Falloon J, Vasudevachari MB, Salzman NP. 1997. Drug resistance during indinavir therapy is caused by mutations in the protease gene and in its Gag substrate cleavage sites. $J$ Virol 71: 6662-6670.

Zhou T, Xu L, Dey B, Hessell AJ, Van RD, Xiang SH, Yang X, Zhang MY, Zwick MB, Arthos J, et al. 2007. Structural definition of a conserved neutralization epitope on HIV-1 gp120. Nature 445: 732-737. 


\section{$\&_{\mathrm{CSH}}^{\infty} \&$ Cold Spring Harbor

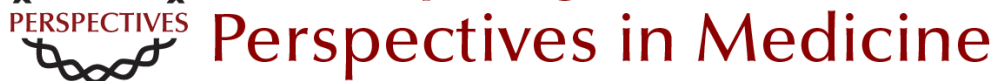

\section{HIV-1 Antiretroviral Drug Therapy}

Eric J. Arts and Daria J. Hazuda

Cold Spring Harb Perspect Med 2012; doi: 10.1101/cshperspect.a007161 originally published online January 25, 2012

\section{Subject Collection HIV}

HIV Pathogenesis: Dynamics and Genetics of

Viral Populations and Infected Cells John Coffin and Ronald Swanstrom

Human Immunodeficiency Virus Vaccine Trials Robert J. O'Connell, Jerome H. Kim, Lawrence Corey, et al.

HIV Transmission George M. Shaw and Eric Hunter

Novel Cell and Gene Therapies for HIV James A. Hoxie and Carl H. June

\section{Behavioral and Biomedical Combination}

Strategies for HIV Prevention Linda-Gail Bekker, Chris Beyrer and Thomas C. Quinn

HIV-1 Assembly, Budding, and Maturation Wesley I. Sundquist and Hans-Georg Kräusslich

HIV-1 Assembly, Budding, and Maturation Wesley I. Sundquist and Hans-Georg Kräusslich

Lessons in Nonhuman Primate Models for AIDS Vaccine Research: From Minefields to Milestones Jeffrey D. Lifson and Nancy L. Haigwood
HIV-1 Pathogenesis: The Virus

Ronald Swanstrom and John Coffin

The T-Cell Response to HIV

Bruce Walker and Andrew McMichael

HIV-1 Reverse Transcription Wei-Shau Hu and Stephen H. Hughes

HIV Pathogenesis: The Host A.A. Lackner, Michael M. Lederman and Benigno Rodriguez

HIV: Cell Binding and Entry Craig B. Wilen, John C. Tilton and Robert W. Doms

Innate Immune Control of HIV Mary Carrington and Galit Alter

HIV DNA Integration

Robert Craigie and Frederic D. Bushman

HIV-1-Related Central Nervous System Disease: Current Issues in Pathogenesis, Diagnosis, and Treatment Serena Spudich and Francisco González-Scarano

For additional articles in this collection, see http://perspectivesinmedicine.cshlp.org/cgi/collection/ 